SZCZARANSKI, Federico. “Aproximación a la reiteración delictiva y a la teoría concursal desde la teoría de la pena"

Polít. crim. Vol. 8, No 16 (Diciembre 2013), Art. 5, pp. 500 - 543.

[http://www.politicacriminal.cl/Vol_08/n_16/Vol8N16A5.pdf]

\title{
Aproximación a la reiteración delictiva y a la teoría concursal desde la teoría de la pena*
}

\author{
Federico León Szczaranski Vargas \\ Licenciado en Ciencias Jurídicas y Sociales, Universidad de Chile \\ Magister en Derecho Penal, Universidad de Talca y Universidad Pompeu Fabra. \\ Centro de Estudios Penales y Penitenciarios, Facultad de Derecho Universidad Mayor. \\ f.szczaranskiv@gmail.com
}

\section{Resumen}

El artículo comienza con una breve exposición de las principales teorías actuales sobre la función de la pena, reconociendo el predominio de la prevención especial como función primordial de la ejecución penal, al igual que el auge experimentado por las modernas teorías expresivo-retributivas, y su relación con una teoría preventivo general positiva como la de Jakobs. A continuación, se analiza la posibilidad de explicar el tratamiento que reciben los diversos supuestos de reiteración delictiva desde las finalidades que postulan las distintas teorías de la pena. Así, se distinguen cinco supuestos de reiteración delictiva y se determina la cualidad distintiva de cada uno de ellos: el concurso aparente (incluyendo casos de especialidad, subsidiaridad y consunción), el delito continuado, el concurso real, la reincidencia y el concurso ideal. En base a ello se analiza el tratamiento que cada teoría de la pena debería otorgarle para favorecer la función primordial que atribuye a la sanción penal.

Palabras clave: Reiteración delictiva, teorías de la pena, concurso aparente, prevención especial, retribución.

\begin{abstract}
The article begins with a brief outline of the main current theories on the role of punishment, recognizing both the dominance of special prevention as the primary function of criminal law enforcement, and the boom experienced by modern expressive-retributive theories, and its relationship with a positive general prevention theory as the one held by Jakobs. Then, the possibility to explain the treatment given to the different cases of criminal reiteration from the purposes posited by the different theories of punishment is analyzed. Thus, five cases of criminal reiteration are distinguished and the distinctive quality of each is determined: the apparent concurrency (including specialty cases, subsidiarity and consumption), the continuing offense, the real concurrence, recidivism and ideal concurrence. This allows analyzing the treatment that each theory of punishment should grant to every criminal reiteration case in order to support the central role attributed to criminal punishment.
\end{abstract}


SZCZARANSKI, Federico. “Aproximación a la reiteración delictiva y a la teoría concursal desde la teoría de la pena”

Key words: Criminal reiteration, theories of punishment, apparent concurrence, special prevention, retribution.

\section{Introducción}

La reiteración delictiva corresponde a aquellos supuestos en que a un mismo sujeto le son imputables múltiples realizaciones de uno o varios tipos penales; es decir, tiene lugar en caso que el comportamiento de una persona infrinja distintas normas de conducta, o varias veces la misma norma, ${ }^{1}$ pudiendo imputársele cada una de esas infracciones.

Siendo ello así, la operación por defecto del derecho penal exigiría aplicar las penas correspondientes a cada uno de los tipos penales realizados, ${ }^{2}$ ya que si el comportamiento ordenado por la norma primaria corresponde a la formulación invertida del supuesto de hecho de la norma de sanción, entonces por cada infracción de la norma primaria se ha igualmente verificado el supuesto de hecho de la norma secundaria, siendo -en principioaplicable la pena establecida para cada realización típica tantas veces como realizaciones típicas hayan tenido lugar.

Ello ocurriría incluso en los casos más tradicionales de concurso aparente, ya que quien mata a su padre -suponiendo una regulación que, a diferencia de la chilena, no establezca una regla de subsidiaridad expresa- realiza tanto el supuesto de hecho de la norma de homicidio, como el de parricidio: el comportamiento realizado por el autor soporta -al menos-dos descripciones: "matar a un ascendiente" y "matar a otro", por lo que constituye un particular subsumible en ambos universales. ${ }^{3}$ La alternativa contraria, es decir, el entendimiento de que la conducta realizada no verifica el supuesto de hecho de ambas normas, descansa en un "punto de partida hermenéutico", conforme al cual, la constatación de un concurso aparente es la constatación de una recíproca exclusión de los tipos penales. Para ello se recurre a la inclusión de elementos negativos del tipo, implícitos, en uno de los delitos que configuran el concurso aparente, en este caso, en el tipo de homicidio, el cual

\footnotetext{
*Este trabajo forma parte del proyecto de investigación Fondecyt $\mathrm{N}^{\circ} 11121313$ referido a Reiteración Delictiva, cuyo investigador responsable es el Dr. Francisco Maldonado Fuentes, a quien agradezco por sus valiosos comentarios. Agradezco igualmente la Juan José Rondón por revisar y comentar una versión preliminar de este artículo.

${ }^{1}$ En los términos originales de Merkel: "los caracteres constitutivos de una misma especie de delito han sido efectuados varias veces, ó bien que se han efectuado caracteres constitutivos de diferentes especies de delitos". MERKEL, Adolf, Derecho penal, Trad.: DORADO, Pedro, Madrid: La España Moderna, 1910, p. 378.

${ }^{2}$ En palabras de Feuerbach: "la pena de cada ley penal encontrará aplicación siempre que los presupuestos para la pena legal estuvieren dados, de lo que se deduce que: 1) Cuando hayan sido infringidas varias leyes penales, se aplicarán las penas de todas las leyes penales infringidas; 2) Cuando una ley penal haya sido infringida varias veces, está jurídicamente fundada la imposición de la pena de la misma tantas veces como haya sido infringida". FEUERBACH, Anselm, Tratado de derecho penal común vigente en Alemania, Trad.: ZAFFARONI, Raúl; HAGEMEIER, Irma, Buenos Aires: Hammurabi, 1989, p. 123.

${ }^{3}$ MAÑALICH, Juan Pablo, "El concurso de delitos: base para su reconstrucción en el derecho penal de Puerto Rico", Revista Jurídica UPR, Vol. 74 (2005), pp. 1001 y ss.
} 


\section{Polít. crim. Vol. 8, № 16 (Diciembre 2013), Art. 5, pp. 500 - 543. [http://www.politicacriminal.cl/Vol_08/n_16/Vol8N16A5.pdf]}

consistiría entonces en matar a un extraño. ${ }^{4}$ Ello importaría entender que al matar al padre no se estaría realizando el supuesto de hecho del tipo de homicidio, ni habría reiteración delictiva alguna. Pero si ello fuera así, entonces quien mata a su padre, sin siquiera haber podido saber de la relación que los liga, deberá quedar impune por fracasar el tipo subjetivo respecto del parricidio, y por no configurarse el tipo objetivo del homicidio.

Descartada esta alternativa referida a la exclusión recíproca de los supuestos de hecho, la única posibilidad que parecería restar para evitar la doble punición sólo en base a consideraciones normativas, sería alegar una antinomia entre las consecuencias jurídicas establecidas en las normas de sanción de cada uno de los tipos involucrados. Pero esa antinomia normalmente no podrá ser alegada, ya que ella requiere que no sólo las consecuencias jurídicas establecidas sean distintas, sino que deben ser excluyentes, ${ }^{5}$ es decir, no debe ser posible cumplir con las dos normas de sanción involucradas; pero no hay incompatibilidad entre una pena de $\mathrm{X}$ años de privación de libertar con otra pena de $\mathrm{Y}$ años de privación de libertad, ya que si bien son distintas, la obligación de imponer la pena de X años de cárcel, emanada de la norma de sanción de uno de los tipos, no constituye ni una prohibición ni una permisión de abstenerse ${ }^{6}$ de imponer la pena de $\mathrm{Y}$ años de cárcel, obligación emanada de la norma de sanción del otro tipo en concurso aparente. Por tanto, nos encontramos con que normativamente deberían tener lugar las consecuencias jurídicas establecidas para la realización de ambos tipos. Ello significa que ni siquiera el caso más simple posible de reiteración (concurso aparente por especialidad entre un homicidio y un parricidio) puede ser satisfactoriamente resuelto sin considerar factores independientes a las mismas normas en juego. Ello permite plantear el problema como uno propio de la teoría del razonamiento jurídico, en que ya hemos determinado cuál es el derecho que regula el caso, pero nos preguntamos por la forma correcta de aplicarlo al caso concreto: sabemos que el derecho establece que quien mata a otro debe ser castigado con una pena $X, y$ sabemos también que quien mata a su ascendiente debe ser castigado con una pena Y; pero de todas formas, con ello no sabemos todavía como debemos resolver el caso concreto que se presenta.

Es por ello que la reiteración delictiva parece un campo fértil para el despliegue de efectos por parte de las diversas teorías de la pena. Ellas no son teorías que busquen dar luz sobre el derecho aplicable al caso, por el contrario, parten de la base de que se han identificado adecuadamente las normas de conducta infringidas y que tampoco hay duda sobre las normas de sanción relevantes, pero se preguntan sobre la adecuada forma de comprender la aplicación de ese derecho ya determinado. Parece atendible pensar que si el tratamiento de los distintos supuestos de reiteración no puede explicarse únicamente recurriendo a la

\footnotetext{
${ }^{4}$ PEÑARANDA, Enrique, Concurso de leyes, error y participación en el delito. Un estudio crítico sobre el principio de la unidad de título de imputación, Madrid: Civitas, 1991, pp. 39 a 41.

${ }^{5}$ BOBBIO, Norberto, Teoría general del Derecho, Trad.: ROZO ACUÑA, Eduardo, Bogotá: Temis, 1992, pp. 184 y ss.

${ }^{6}$ VON WRIGHT, Georg Henrik, Norma y acción. Una investigación lógica, Trad.: GARCÍA FERRERO, Pedro, Madrid: Tecnos, 1970, pp. 151 y ss.; HRUSCHKA, Joachim, "Sobre la utilidad del hexágono deontológico para el derecho", Trad.: SÁNCHEZ-OSTIZ, Pablo; en: HRUSCHKA, Joachim, Imputación y derecho penal. Estudios sobre la teoría de la imputación. Navarra: Aranzadi S.A., 2005, pp. 43 y ss.
} 
operación mecánica de de la norma primaria como habilitación para la aplicación de la secundaria, entonces corresponda a las diversas concepciones acerca de la función de esa norma secundaria lo que explique la desviación de la solución por defecto.

Así, una vez que se ha establecido la existencia de reiteración delictiva, debería ser posible responder desde las diversas teorías de la pena la forma en que cada supuesto de reiteración debe ser tratado. Para ello se deberá determinar los elementos distintivos de cada forma de reiteración, y preguntarse por la manera en que esa cualidad diferenciadora debería ser entendida desde las diversas aproximaciones al castigo, de forma tal que la misma propiedad que desde una corriente prevencionista podría fundamentar un tratamiento privilegiado, por ser expresiva de menores necesidades preventivas, puede simultáneamente justificar, desde la óptica retributiva, un tratamiento más severo.

\section{La pena.}

Puesto que la reiteración delictiva corresponde a una institución relacionada dogmáticamente con la determinación de la pena, el estudio que a continuación se inicia se enmarca en las teorías de la pena actualmente dominantes. Entre ellas, las finalidades preventivo-especiales son las que en este momento tienen preeminencia en la discusión sobre la teoría de la pena. Las teorías retributivas se vieron muy disminuidas durante la mayor parte del Siglo XX, por cuanto el entendimiento del derecho penal como un sistema destinado y justificado por la protección de bienes jurídicos no resulta fácilmente compatible con una concepción de la pena que niega relevancia a ese efecto; lo que llevó a Hassemer, en 1982, a afirmar que la visión retribucionista "ya no es válida en la teoría de la pena”, la cual es dominada por una política-criminal orientada a fines de prevención. ${ }^{8}$

La teoría de la prevención general negativa, por su lado, constituye más una teoría preventiva sobre el fundamento de la conminación penal que una doctrina sobre la función de la sanción una vez que el delito ya ha sido cometido. Así, para que el Estado pueda cumplir con su deber de evitar que se afecte la libertad garantizada estatalmente, éste tiene correlativamente el derecho a buscar mecanismos coactivos que impidan las lesiones jurídicas. Por ello, señala Feuerbach, y dada la insuficiencia de la coerción física inmediata, el Estado recurre a la pena como una forma de coacción psicológica que advierte de un mal superior al placer que el delincuente obtendría en caso de realizar la acción prohibida, cancelando así el impulso sensual delictivo. ${ }^{9}$ Por lo mismo, esta teoría no parece dejar mucho espacio para formular ideas generales sobre el tratamiento que debe otorgarse a los casos en estudio, ya que al momento en que se deben analizar los diversos supuestos de reiteración, la prevención general negativa ya ha fracasado en su labor de desincentivar al ilícito, restando sólo la aplicación de la sanción con la finalidad de "dar fundamento

\footnotetext{
${ }^{7}$ MAÑALICH, "El concurso", cit. nota n 3, p. 1023.

${ }^{8}$ HASSEMER, Winfried, "Fines de la pena en derecho penal"; en: MIR, Santiago (Ed.), Derecho penal y ciencias sociales, Barcelona: Universidad Autónoma de Barcelona, 1982, p. 118.

${ }^{9}$ FEUERBACH, Tratado, cit. nota n ${ }^{\circ} 2$, pp. 59 a 61.
} 


\section{Polít. crim. Vol. 8, N 16 (Diciembre 2013), Art. 5, pp. 500 - 543. [http://www.politicacriminal.cl/Vol_08/n_16/Vol8N16A5.pdf]}

efectivo a la conminación", la cual en caso de no ser aplicada "quedaría hueca". ${ }^{10}$ Ello es coincidente con que en la dominante teoría de la unión, esta corriente no juega un rol especialmente relevante, sino respecto de la conminación penal.

Por su parte, una versión positiva de la prevención general puede encontrarse en dos variantes, dependiendo de si a la pena se le asigna una función normativa, consistente en restablecer la vigencia de la norma infringida, o si a ella se le atribuyen efectos psicológicos referidos a reafirmar la confianza en la vigencia de esa norma. ${ }^{11}$

Mientras que la primera formulación configura una teoría absoluta de la pena, en que ella no constituye un medio para un fin ulterior, puesto que la pena derechamente constituye el restablecimiento de la norma primaria, en la segunda concepción la prevención configura una teoría relativa. Un antecedente de esta última formulación de la prevención general positiva puede encontrarse en Carrara, para quien la pena se justifica por su faz positiva, de construcción y de protección, ${ }^{12}$ consistente en mantener el orden determinado por la ley de dios. ${ }^{13}$ Igualmente, en Welzel se destacan los aspectos positivos de la pena referidos a la observancia de valores, exteriorizando mediante la sanción la validez inviolable de

${ }^{10}$ FEUERBACH, Tratado, cit. nota $\mathrm{n}^{\circ}$ 2, pp. 60 y 61. En Feuerbach, la cantidad de lesiones jurídicas, entendidas como afectaciones de derechos, tiene relevancia para la determinación de la magnitud de la pena, tanto en un análisis objetivo, referido al número de lesiones que ha tenido lugar; como en razón de los fundamentos subjetivos de la punibilidad, sede en la cual se considera el "ámbito" de la voluntad del autor, de forma tal que habrá mayor punibilidad en consideración a que la voluntad del autor se dirija a una pluralidad de derechos y sujetos afectados (pp. 114, 119 y 121). Ello conlleva que como regla general se postule, en el $\S$ 129, que deberá haber sanción por cada infracción a la ley penal. Pero se admite, en caso de imposibilidad por naturaleza de aplicar todas las penas conjuntamente, y también en atención a "principios jurídicos superiores", que se haga excepción y se aplique solo la pena mayor -caso del concurso ideal entre crímenes del mismo género, delito continuado- o ésta con un complemento consistente en parte de las penas restantes -concurso ideal entre crímenes de géneros diversos- (§ 130 y 131). La referencia que se hace a "principios jurídicos superiores" parece indicar que no es posible desde la misma lógica de la prevención general negativa, justificar la no aplicación de una sanción referida a una prohibición o mandato infringido. Ello significaría que no es posible ofrecer razones internas por las cuales la aplicación de una única sanción serviría para la confirmación de la seriedad de la amenaza establecida en más de una ley penal.

En términos similares, también propios de la prevención general negativa, Manzini afirma que se justifica la penalidad en la medida que el Estado considera necesario crear nuevos motivos para la abstención de las conductas referidas en el precepto penal, de forma que ese motivo sea predominante. En ese esquema, una de las finalidades de la ejecución es convencer a todos de la seriedad de la conminación (MANZINI, Vicenzo, Tratado de Derecho Penal. Tomo 1. Primera Parte. Teorías Generales, Trad.: SENTÍS, Santiago, 9 Ed., Buenos Aires: Ediar, 1949, p. 101); agregando que si no se aplicara la pena conminada, entonces decaería la confianza en la tutela del estado (MANZINI, Vicenzo, Tratado de Derecho Penal. Tomo 4. Primera Parte. Teorías Generales, Trad.: SENTÍS, Santiago, 9 Ed., Buenos Aires: Ediar, 1949, p. 4).

${ }^{11}$ MIR PUIG, Santiago, "Función fundamentadora y función limitadora de la prevención general positiva"; en: BUSTOS, Juan (Dir.), Prevención y teoría de la pena, ConoSur Ltda., 1995, p. 50

${ }^{12}$ HASSEMER, "Fines de la pena", cit. nota ${ }^{\circ} 8$, p. 134.

${ }^{13}$ CARRARA, Francesco, Opúsculos de derecho criminal. Volumen I, Trad.: ORTEGA, José; GUERRERO, Jorge, Santa fe de Bogotá: Temis, 2000, pp. 100 y 101. 
SZCZARANSKI, Federico. “Aproximación a la reiteración delictiva y a la teoría concursal desde la teoría de la pena”

aquellos. ${ }^{14}$ Con ello se asigna a la pena una función positiva consistente en asegurar la vigencia de los valores ético-sociales elementales. ${ }^{15}$

En este marco, la preeminencia de la teoría de la unión en la doctrina dominante importa que sean consideraciones de prevención especial las que deban ser prioritariamente atendidas una vez que se haya afirmado la existencia de uno o más delitos; es decir, establecida la concurrencia de una hipótesis de reiteración delictiva, en la actualidad deberá atenderse de manera fundamental a consideraciones preventivo-especialmente relevantes para determinar el tratamiento que corresponda a cada supuesto de reiteración.

Si bien en Beccaria se hace referencia expresa al rol preventivo especial que debe cumplir la pena, indicando que ésta debe impedir al reo causar nuevos daños, ${ }^{16}$ es posiblemente von Liszt el primero que ofrece una versión acabada de la teoría preventivo-especial. Él entiende que la mejor manera en que la pena puede cumplir su finalidad protectora de bienes es considerando al momento de su aplicación a cada infractor en concreto. ${ }^{17}$ De ahí viene la famosa clasificación de von Liszt: se corrige a los corregibles que necesiten corrección; se intimida a los que no necesitan corrección, y se neutraliza a los no corregibles. ${ }^{18}$ Esta aproximación, que busca alejarse de dogmatismos que se han "perdido en luchas estériles", ${ }^{19}$ es compartida y maximizada luego por la corriente de la nueva defensa social, movimiento que busca dar con una adecuada individualización de la pena en función de las características del sujeto penado. Así, se configura una concepción general de derecho penal que trata de no penar la culpa, ni sancionar la infracción a una regla; sino de proteger a la sociedad contra actividades criminales, disminuyendo la delincuencia y favoreciendo la reinserción social. De esta forma, se favorece la prevención individual centrada en la resocialización. ${ }^{20}$

Esta idea, conforme a la cual la pena no tiene por finalidad reprochar la culpabilidad del autor, sino que intervenir sobre este en post de finalidades preventivas, es compartida -en lo relevante- por las distintas variantes de la teoría de la unión, desde Merkel $^{21}$ a Roxin, ${ }^{22}$

\footnotetext{
${ }^{14}$ WELZEL, Hans, Derecho penal parte general, Trad: FONTÁN BALESTRA, Carlos; Buenos Aires: Roque De Palma Editor, 1956, p. 3.

${ }^{15}$ WELZEL, Derecho penal, cit. nota $\mathrm{n}^{\circ} 14$, p. 7. Por ello, el autor comienza su trabajo indicando que la misión del derecho penal se encuentra en el amparo de los valores elementales de la vida en comunidad (p. 1).

${ }^{16}$ BECCARIA, Cesare, De los delitos y de las penas, Trad.: DE LAS CASAS, Juan, Madrid: Alianza editorial, 2002, p. 51.

${ }^{17}$ VON LISZT, Franz, La idea de fin en el derecho penal, México: Instituto de Investigaciones Jurídicas, 1994, p. 106

${ }^{18}$ VON LISZT, La idea, cit. nota $\mathrm{n}^{\circ} 17$, p. 115

${ }^{19}$ VON LISZT, La idea, cit. nota $\mathrm{n}^{\circ} 17$, p. 132.

${ }^{20}$ JIMÉNEZ DE ASÚA, Luis, El criminalista. $2^{\circ}$ Serie. Tomo V, Buenos Aires: Víctor P. de Zavalía, 1961, p. 23.

${ }^{21}$ MERKEL, Derecho, cit. nota ${ }^{\circ} 1$, p. 270.

${ }^{22}$ ROXIN, Claus, Derecho penal. Parte general. Tomo I, Trad.: LUZÓN PEÑA, Diego Manuel; DÍAZ Y GARCÍA CONLLEDO, Miguel; DE VICENTE REMESAL, Javier, Madrid: Civitas, $2^{\circ}$ ed., 1997, p. 97; seguido por MIR, Santiago, Introducción a las bases del derecho penal. Concepto y método, MontevideoBuenos Aires: B de F, $2^{\circ}$ ed., 2003, pp. 90 y ss.
} 
Polít. crim. Vol. 8, № 16 (Diciembre 2013), Art. 5, pp. 500 - 543.

[http://www.politicacriminal.cl/Vol_08/n_16/Vol8N16A5.pdf]

pasando por Jescheck, ${ }^{23}$ Maurach, ${ }^{24}$ Stratenwerth, ${ }^{25}$ Zipf, $^{26}$ Schünemann ${ }^{27}$ y Frister, este último indicando que se debe rescatar de von Liszt la idea de configurar la pena de modo que ella tenga efectos contrarios a la comisión de delitos por parte del autor. ${ }^{28}$ En ellas, en todo caso, la persecución de finalidades preventivas generalmente se encuentra restringida, en su límite superior, por el principio de culpabilidad, impidiéndose la aplicación de una pena que, siendo preventivo-especialmente adecuada, resulta excesiva respecto de la culpabilidad del condenado; ${ }^{29}$ y en su parte inferior, por necesidades preventivo generales positivas, referidas a casos en que una pena cuya baja magnitud es recomendada por consideraciones preventivas, no puede imponerse si con ella se afecta "la defensa del ordenamiento jurídico", es decir, en caso que la baja magnitud resultare "incomprensible para la sensibilidad jurídica general". 30

Ese esquema permite dar paso, al momento de la determinación judicial de la pena, a la actualmente dominante teoría del espacio de juego. Conforme a ella, "La pena adecuada a la culpabilidad no puede ser exactamente determinada. Existe un espacio de juego, que está delimitado, por arriba, por la pena ya adecuada a la culpabilidad y, por debajo, por la pena todavía adecuada a la culpabilidad. El juez no puede sobrepasar el límite superior. No está autorizado a imponer una pena tan severa en cuanto al tipo y cantidad que no sea ya, según su apreciación adecuada a la culpabilidad. El juez puede, sin embargo decidir según su criterio en qué medida debe aplicar la pena dentro del espacio de juego". 31 Ello quiere decir, en palabras de Zipf, que se previene dentro del marco que entrega la culpabilidad,

23 JESCHECK, Hans-Heinrich; WEIGEND, Thomas, Tratado de Derecho Penal. Parte General, Trad: OLMEDO, Manuel, Granada: Editorial Comares, $5^{\circ}$ ed., 2002, p. 81.

${ }^{24}$ MAURACH, Reinhart; ZIPF, Heiz, Derecho Penal. Parte General I. Teoría General del derecho penal y estructura del hecho punible, Trad.: BOFILL, Jorge; AIMONE, Enrique, Buenos Aires: Astrea, $7^{\circ}$ Ed., 1994, pp. 104 y ss.

${ }^{25}$ STRATENWERTH, Günther, Derecho Penal. Parte General I. El hecho punible, Trad.: CANCIO MELIÁ, Manuel; SANCINETTI, Marcelo, Navarra: Aranzadi, 2005, pp. 38 a 40;

${ }^{26}$ ZIPF, Heinz, "Principios fundamentales de la determinación de la pena", Cuadernos de política criminal $\mathrm{n}^{\circ}$ 17 (1982), pp. 354 y 358 especialmente.

27 SCHÜNEMANN, Bernd, "La función en el principio de culpabilidad en el derecho penal preventivo", Trad.: SILVA SÁNCHEZ, Jesús, en: SCHÜNEMANN, Bernd, El sistema moderno de derecho penal. Cuestiones fundamentales, Madrid: Tecnos, 1991, pp. 162 y 163

28 FRISTER, Helmut, Derecho penal. Parte General, Trad.: SANCINETTI, Marcelo, Buenos Aires: Hammurabi, 2009, pp. 66 y 71.

${ }^{29}$ SCHÜNEMANN, "La función”, cit. nota ${ }^{\circ} 27$, p. 151.

${ }^{30}$ ROXIN, Claus, "Determinación de la pena a la luz de la teoría de los fines de la pena", en: ROXIN, Claus, Culpabilidad y prevención en Derecho Penal, Trad.: MUÑOZ CONDE, Francisco, Madrid: Reus S.A., 1981, p. 109. Véase también: ZIFFER, Patricia, Lineamientos de la determinación de la pena, Buenos Aires: AdHoc, 1996, pp. 46 y 47; MUÑOZ CONDE, Francisco, "La resocialización del delincuente análisis y crítica de un mito"; en: Homenaje al profesor J. Antón Oneca, Salamanca: Ediciones Universidad de Salamanca, 1982, pp. 338 y 339.

${ }^{31}$ DEMETRIO CRESPO, Eduardo, "Notas sobre la dogmática de la individualización judicial de la pena", Revista Jurídica de Castilla la Mancha $\mathrm{n}^{\circ} 35$ (2003), p. 23. En contra de la teoría del espacio de juego: SILVA, Jesús, "La teoría de la determinación de la pena como sistema (dogmático): un primer esbozo"; Indret, Abril 2007, pp. 3 a 5, por cuanto con ello se separa la determinación de la pena de la teoría del delito. 
SZCZARANSKI, Federico. “Aproximación a la reiteración delictiva y a la teoría concursal desde la teoría de la pena”

debiendo para ello separarse el ámbito de aquella y el de la prevención, los cuales se regirían por valoraciones distintas. ${ }^{32}$

Así las cosas, el retribucionismo llegó a quedar reducido a jugar un papel secundario en las teorías mixtas de la pena, consistente en limitar, junto con la prevención general, la persecución de finalidades preventivo-especiales.

Ello experimentó una importante modificación explicada -entre otros factores- por la irrupción del trabajo de Jakobs y su teoría funcional de derecho penal; la cual especialmente en su segundo estadio $-{ }^{33}$ configura una teoría de corte hegeliana, ciega a los efectos empíricos que ella produzca en el mundo, ${ }^{34}$ y que puede ser caracterizada como una teoría retributiva radicalmente funcional y anti-psicologista. ${ }^{35}$ Ello, y sumado a los esfuerzos de autores como Hörnle, Kindhäuser, Mañalich, y a toda una corriente angloamericana neoretribucionista (fortalecida por el auge del nothing works); ha supuesto en los últimos tiempos un auge de las teorías absolutas de la pena, conforme a las cuales el castigo se considera como algo bueno en sí mismo, sin prestar atención a un determinado fin que podría ser alcanzado mediante aquel. ${ }^{36}$

Así, tanto la teoría retributiva de Kindhäuser y Mañalich, como la defendida por von Hirsch y Hörnle, afirman que la pena cumple una función expresiva de reproche por una conducta defectuosa $^{37}$. Las diferencias entre ambas corrientes se advierten, en primer término, por lo que define en cada caso el carácter reprochable de la acción. Mientras que para los primeros la reprochabilidad de la conducta descansará en que ella expresará un déficit de fidelidad por la vulneración de una norma en cuya creación el autor pudo participar; ${ }^{38}$ en el caso de von Hirsch y Hörnle el reproche se fundamenta en una cualidad material, sustantiva de la

${ }^{32}$ ZIPF, "Principios", cit. nota n' 26, pp. 357 y 358.

${ }^{33}$ CANCIO MELIÁ, Manuel; FEIJOO SÁNCHEZ, Bernardo, “¿Prevenir riesgos o confirmar normas? La teoría funcional de la pena de Günther Jakobs"; en: JAKOBS, Günther, La pena estatal: significado y finalidad, Trad: CANCIO MELIÁ, Manuel; FEIJOO SÁNCHEZ, Bernardo; Navarra: Civitas, 2006.

${ }_{34}$ JAKOBS, Günther, Sobre la teoría de la pena, Bogotá: Ed. Universidad Externado de Colombia, 1998.

${ }^{35}$ JAKOBS, Günther, La pena estatal: significado y finalidad, Trad: CANCIO MELIÁ, Manuel; FEIJOO SÁNCHEZ, Bernardo; Navarra: Civitas, 2006, p. 41.

${ }^{36}$ MAURACH/GÖSSEL/ZIPF, Parte General I., cit. nota ${ }^{\circ}$ 24, p. 86; JESCHECK; WEIGEND, Tratado, cit. nota $\mathrm{n}^{\circ} 23$, p. 75; FEIJOO, Bernardo, Retribución y prevención general. Un estudio sobre la teoría de la pena y las funciones del derecho penal, Montevideo-Buenos Aires: B de f, 2007, p. 63; ROXIN, Derecho penal, cit. nota $\mathrm{n}^{\circ} 22$, p. 82; MAÑALICH, Juan Pablo, "Retribución como coacción punitiva", Derecho y humanidades $\mathrm{n}^{\circ} 16$ (2010), p. 62.

${ }^{37}$ FEINBERG, Joel, "The expressive function of punishment"; en: FEINBERG, Joel, Doing \& deserving. Essays in the theory of responsibility, Princeton, New Jersey: Princeton University Press, 1974, pp. 98 y 99. En términos similares: ROSS, Alf, On guilt, responsibility and punishment, Berkley and Los Angeles, California: University of California Press, 1975, pp. 37 y 38.

${ }^{38}$ KINDHÄUSER, Urs, "La fidelidad al derecho como categoría de la culpabilidad", Trad.: MAÑALICH, Juan Pablo, en: KINDHÄUSER, Urs; MAÑALICH, Juan Pablo, Pena y culpabilidad en el estado democrático de derecho, Perú: ARA Editores, 2009, pp. 100 y 101; MAÑALICH, Juan Pablo, "La pena como retribución", Estudios Públicos n 108 (2007), p. 187; MAÑALICH, Juan Pablo, "Pena y ciudadanía", Revista de estudios de la justicia $\mathrm{n}^{\circ} 6$ (2005), pp. 65 y ss. 


\section{Polít. crim. Vol. 8, N 16 (Diciembre 2013), Art. 5, pp. 500 - 543. [http://www.politicacriminal.cl/Vol_08/n_16/Vol8N16A5.pdf]}

conducta realizada, dependiente -si nos centramos sólo en el harm principle ${ }^{39}$ del daño que ha causado y de la culpabilidad del autor. ${ }^{40}$ Para la determinación de lo que constituye un daño, ambos autores consideran que la perspectiva de la víctima debe ser adoptada para determinar lo materialmente reprochable del acto, ${ }^{41}$ y desde ahí afirman que el daño deberá entenderse como una afectación de condiciones normalmente esenciales para una calidad de vida dada, la cual se define de manera no individualizada, ${ }^{42}$ recurriendo entonces a un concepto objetivo relativo a recursos típicamente necesarios para alcanzar una calidad de vida segura. $^{43}$

Ahora bien, junto con ello, a la expresión de reproche von Hirsch agrega como función secundaria de la pena la consecución de finalidades preventivas, sosteniendo que aquellos que no se motiven sólo por la censura, verán en la amenaza de pena una razón de prudencia adicional para la abstención de la realización del tipo, lo que supone ver en el sujeto a un ser moral falible, pero no a una bestia controlable sólo por miedo. ${ }^{44}$ Por otro lado, la opción de Kindhäuser y Mañalich no consideran esos efectos preventivos, y en cambio afirman que junto con el reproche tiene lugar un efecto preventivo general positivo: "en tanto respuesta

\footnotetext{
${ }^{39}$ Junto al cual se considera el paternalismo, que podría justificar el derecho penal en la medida que lo la medida paternalista aumente la autodeterminación de los afectados por ella (VON HIRSCH, Andrew, Censurar y castigar, Trad.: LARRAURI, Elena, Madrid: Editorial Trotta S.A., 1998, p. 52.); y la ofensividad, la cual se referiría la injusta producción de sentimientos indeseados (VON HIRSCH, Andrew, "El concepto de bien jurídico y el <principio del daño>", Trad.: ALCACER, Rafael, en: HEFENDEHL, Roland, La teoría del bien jurídico: ¿fundamento de legitimación del derecho penal o juego de abalorios dogmáticos?, Madrid: Marcial Pons, 2007, p. 50). Al respecto, véase igualmente HÖRNLE, Tatjana, "Offensive behavior and German penal law", Buffalo Criminal Law Review, Vol. 5 (2001); HÖRNLE, Tatjana, "La protección de sentimientos en el StGB", Trad.: MARTÍN LORENZO, María, en: HEFENDEHL, Roland, La teoría del bien jurídico: ifundamento de legitimación del derecho penal o juego de abalorios dogmáticos?, Madrid: Marcial Pons, 2007.

${ }^{40}$ VON HIRSCH, Andrew, "Seriousness, severity and the living standard"; en: VON HIRSCH, Andrew; ASHWORTH, Andrew; ROBERTS, Julian, Principled sentencing. Reading on theory and policy, Oregon: HART Publishing, 2009, p. 143. Factores a los cuales Hörnle agrega la "responsabilidad subjetiva" referida a las intenciones del autor o a la negligencia involucrada (HÖRNLE, Tatjana, Determinación de la pena y culpabilidad. Notas sobre la teoría de la determinación de la pena en Alemania, Trad.: FRANCHINI, María Belén, Buenos Aires: Fabián J. Di Plácido, 2003, pp. 33).

${ }^{41}$ HÖRNLE, Tatjiana, "Distribution of punishment: The role of a victim's perspective"; en: Buffalo Criminal Law Review, Vol. 3 (1999), p. 185.

${ }^{42}$ HÖRNLE, "Distribution", cit. nota n ${ }^{\circ} 41$, pp. 185 y ss. VON HIRSCH, "Seriousness", cit. nota n 40, p. 144. Igualmente: VON HIRSCH, Censurar y castigar, cit. nota n 39, pp. 62 a 67.

${ }^{43}$ HÖRNLE, "Distribution", cit. nota n ${ }^{\circ} 41$, pp. 189 y 193. Igualmente: VON HIRSCH, Censurar y castigar, cit. nota $\mathrm{n}^{\circ} 39$, pp. 62 a 67.

${ }^{44}$ VON HIRSCH, Andrew, "Proportionate sentences: a Desert perspective"; en: VON HIRSCH, Andrew; ASHWORTH, Andrew; ROBERTS, Julian. Principled sentencing. Reading on theory and policy, Oregon: HART Publishing, 2009, pp. 117 y 118; igualmente en: VON HIRSCH, Censurar y castigar, cit. nota n ${ }^{\circ}$ 39, p. 41. Cercano a ello se encuentra la propuesta de Duff, conforme a la cual el castigo debe retribuir, reparar y lograr finalidades preventivo especiales (DUFF, Anthony, "Restoration and retribution"; en: VON HIRSCH, Andrew; ROBERTS, Julian; BOTTOMS, Anthony (Eds.), Restorative Justice and Criminal Justice Competing or Reconcilable Paradigms?, Oxford, Portland and Oregon: Hart Publishing, 2003, p. 48; DUFF, R. A., "Probation, punishment and restorative justice: Should all tourism be engage in Punishment?", The Howard Journal, Vol. 42, n² 2 (2003), p. 188).
} 
SZCZARANSKI, Federico. “Aproximación a la reiteración delictiva y a la teoría concursal desde la teoría de la pena”

al quebrantamiento de la norma, la pena ha de declarar -nuevamente de modo comunicativo- que la norma vale sin reservas". 45

Esta dimensión positiva de la pena ha sido notablemente defendida por Jakobs, en su teoría funcional de derecho penal. Entendiendo que la sociedad corresponde a una construcción de un contexto de comunicación cuya identidad se determina por medio normas, las cuales corresponden a reglas de configuración ${ }^{46}$ que a su vez constituyen expectativas normativas eventualmente contrafácticas; ${ }^{47}$ el delito corresponde a una acción cuyo significado es la proposición de una configuración social distinta. ${ }^{48}$ De esta forma, la pena imputa al infractor la discrepancia entre la expectativa y su conducta, y confirma la identidad de la sociedad. $^{49}$ Por ello, no es un medio para mantener la identidad social, sino que ya constituye ese mantenimiento mismo, ${ }^{50}$ con independencia de los efectos psicológicos de intimidación que se alcancen. ${ }^{51}$

\section{Los supuestos de reiteración.}

Un presupuesto para el estudio de la reiteración es un adecuado análisis de las diferentes estructuras a nivel de acción que se encuentran en los distintos supuestos de reiteración delictiva. Para ello, se utilizará el siguiente modelo: la acción, como unidad jurídica, puede fundamentarse desde dos perspectivas: (1) la unidad típica de acción, referida a casos en los que la descripción de la conducta típica requiere la realización de más de un movimiento corporal o de una omisión (delitos permanentes y complejos), no obstante lo cual, jurídicopenalmente se afirmará una única acción; y (2) unidad natural de acción, la cual puede explicarse por una realización (2.1.) reiterativa del tipo penal, caso en que varias acciones inmediatamente sucedidas realizan otras tantas veces el mismo tipo penal, o por una realización (2.2.) sucesiva del tipo penal, en que la consumación del delito tiene lugar luego de una sucesión de actos, los cuales constituyen realizaciones típicas independientes, ${ }^{52}$

\footnotetext{
${ }^{45}$ KINDHÄUSER, Urs, "La lógica de la construcción del delito", Trad.: MAÑALICH, Juan Pablo, Revista de Análisis Especializado de jurisprudencia $\mathrm{n}^{\circ} 14$ (2009), p. 5.

46 JAKOBS, Günther, Sociedad, norma y persona en una teoría de un derecho penal funcional, Trad.: CANCIO MELIÁ, Manuel; FEIJÓO SÁNCHEZ, Bernardo, Madrid: Editorial Civitas, 2000, p. 26.

47 JAKOBS, Günther, Sobre la normativización de la dogmática jurídico-penal, Trad.: CANCIO MELIÁ, Manuel; FEIJÓO SÁNCHEZ, Bernardo, Madrid: Editorial Civitas, 2003, p. 20.

48 JAKOBS, Günther, "El sistema de imputación jurídicopenal. Conocimiento y desconocimiento de la norma”, Trad.: SÁNCHEZ-VERA GÓMEZ-TRELLES, Javier; SANCINETTI, Marcelo A.; CORDOBA, Fernando, en: JAKOBS, Günther; STRUENSEE, Eberhard, Problemas capitales del derecho penal moderno, Buenos Aires: Editorial Hammurabi, 1998, p. 37.

${ }^{49}$ Lo que hace de forma negativa, señalando aquello que no es sociedad; en: CANCIO MELIÁ/FEIJOO, "¿Prevenir", cit. nota n 33, p. 44.

${ }^{50}$ JAKOBS, Sociedad, cit. nota ${ }^{\circ} 46$, p. 17.

51 JAKOBS, Sobre la teoría, cit. nota $\mathrm{n}^{\circ}$ 34, p. 25: la pena importa la constatación de la realidad social sin cambios.

${ }^{52}$ Así: JESCHECK/WEIGEND, Tratado, cit. nota n 23, pp. 766 a 768; STRATENWERTH, Derecho Penal, cit. nota $n^{\circ} 25$, pp. 449 y 459, quien denomina "unidad natural de acción" a los supuestos de unidad jurídica de acción; MIR, Santiago, "Concurso de delitos y concurso de leyes"; en: CONSEJO GENERAL DEL PODER JUDICIAL (ESPAÑA), Temas básicos del derecho: una visión actual, Catalunya, Centre d'Estudis Jurídics i Formació Especialitzada de la Generalitat de Catalunya, 1992, pp. 98 y 99, comparte la identificación de una única acción en función de la realización iterativa y sucesiva, pero afirma pluralidad de
} 


\section{Polít. crim. Vol. 8, № 16 (Diciembre 2013), Art. 5, pp. 500 - 543. [http://www.politicacriminal.cl/Vol_08/n_16/Vol8N16A5.pdf]}

como ocurriría en el paso de la participación a autoría y de tentativas a consumación, respecto de los cuales hay discrepancias en torno a su ubicación. ${ }^{53}$

En paralelo a esta clasificación de la unidad jurídica de acción, es posible proponer una unidad de acción determinada en función del "sentido social de una unidad", conforme al cual varios movimientos u omisiones constituyen una unidad, no por su forma de adecuarse a las distintas descripciones típicas, sino que por ser considerados en la "vida cotidiana" como una unidad, ${ }^{54}$ lo que se ha denominado como "acción en sentido natural". 55 Así, es posible advertir una relación entre la unificación por realización iterativa y la acción en sentido natural: quien da cuatro golpes seguidos a su adversario, generará una unidad natural de acción que sustentará una unidad jurídica de acción, unidad que también se observará desde una "concepción general de la vida". 56

Ahora bien, la aproximación desde una unidad jurídica de acción genera problemas para distinguir entre la realización de un hecho delictivo y la realización de una sola acción. Así, si un delito sanciona el falso testimonio, y otro tipo castiga el falso testimonio en que se acusa a una autoridad, entonces la unidad típica de acción permite advertir una sola acción en toda la secuencia de comportamientos que configuran la realización del falso testimonio, pero al mismo tiempo, esa unificación -en la medida que se entiende que la descripción típica "recorta un determinado fragmento de la actividad humana" y la considera una unidad $-{ }^{57}$ tendrá lugar tantas veces como tipos penales se hubieran realizado, obligando a advertir dos acciones desde la perspectiva jurídica, cada una de las cuales se compone de la misma pluralidad de comportamientos físicos. Igualmente, si de un disparo se causa una muerte y un aborto, se debería advertir dos unidades jurídicas de acción: una por cada satisfacción de un tipo penal.

Así, la delimitación en función de la realización del tipo, sirve tanto para unificar, como para multiplicar las acciones; y ello demandará que cuando se aborden los problemas que se plantean respecto de la "única acción" requerida para la existencia del concurso ideal, se deba recurrir a la unidad de hecho en sentido extensional como criterio de unificación.

acciones cuando tiene lugar una pluralidad de resultados materiales; MAÑALICH, "El concurso", cit. nota ${ }^{\circ}$ 3 , pp. 1029 a 1031 .

53 Así, Matus resuelve por consunción los casos en que el partícipe deviene en autor, y el paso desde la tentativa a la consumación (MATUS, Jean Pierre, "Los criterios de distinción entre el concurso de leyes y las restantes figuras concursales en el código penal español de 1995 (1)", ADPCP, Vol. LVIII (2005), p. 487); mientras que ambos supuestos son para Jescheck, Mir y Stratenwerth casos de subsidiaridad (JESCHECK/ WEIGEND, Tratado, cit. nota $\mathrm{n}^{\circ}$ 23, p. 792; MIR, Santiago, Derecho Penal. Parte General, Barcelona: Reppetor, $9^{\circ}$ Ed., 2011, p. 663; STRATENWERTH, Derecho Penal, cit. nota ${ }^{\circ}$ 25, pp. 456 y 457), Frister, por su parte, incluye en la especialidad a los casos de tentativa y posterior consumación, y en la subsidiaridad los referidos a cambios en la forma de participación (FRISTER, Derecho penal, cit. nota $\mathrm{n}^{\circ} 28$, pp. 682 y 685) ${ }^{54}$ FRISTER, Derecho penal, cit. nota ${ }^{\circ} 28$, p. 669.

55 JESCHECK/WEIGEND, Tratado, cit. nota ${ }^{\circ} 23$, p. 765.

${ }^{56}$ FRISTER, Derecho penal, cit. nota n 28, p. 672; véase también, CUERDA RIEZU, Antonio, "La unidad de delitos en la jurisprudencia del Tribunal Supremo”; en: SILVA SÁNCHEZ, Jesús (ed.), Política criminal y nuevo derecho penal. Libro homenaje a Claus Roxin, Barcelona: Bosch Editor, 1997, p. 346

${ }^{57}$ MIR, Derecho Penal, cit. nota ${ }^{\circ} 53$, p. 650 
SZCZARANSKI, Federico. “Aproximación a la reiteración delictiva y a la teoría concursal desde la teoría de la pena”

\subsection{Concurso aparente.}

El primer supuesto de reiteración a ser analizado será los casos de concurso aparente de leyes penales. Respecto de ellos, es bastante extendida la afirmación conforme a la cual en estos casos si bien hay dos normas en principio aplicables, con sólo una de ellas basta para captar por sí sola la totalidad del desvalor de la conducta, comprendiendo así completamente el contenido de ilícito. ${ }^{58}$

Esa posibilidad de captar la totalidad del injusto mediante sólo uno de los tipos concurrentes, tendría lugar en los casos de especialidad, subsidiaridad y consunción. ${ }^{59}$ A pesar de haber diferencias y matices en la caracterización de estos supuestos, parece acertado afirmar que en general, la especialidad consiste en una relación entre los tipos en juego que se advertiría del puro examen formal de los enunciados legales, ${ }^{60}$ conforme a la cual resulta imposible realizar uno de los tipos sin realizar también el otro, ${ }^{61}$ ya que aquel que capta la totalidad del injusto contiene todos los elementos del primero, más uno adicional. $^{62}$

Por su parte, la subsidiaridad también podría explicarse en función de relaciones lógicas entre los tipos involucrados, ${ }^{63}$ y corresponde al caso en que uno de los tipos sólo entra en consideración si el otro no es aplicable, y ello podría tener lugar tanto si ese condicionamiento es expreso en la ley (caso en el cual difícilmente podría hablarse de concurso), como si debe deducirse en base a consideraciones teleológicas, ${ }^{64}$ las cuales referirían no sólo a relaciones de tipos distintos, particularmente en el caso en que pasa

\footnotetext{
${ }^{58}$ MAURACH, Reinhart; GÖSSEL, Karl; ZIPF, Heiz, Derecho Penal. Parte General II. Formas de aparición del delito y consecuencias del hecho punible, Trad.: BOFILL, Jorge, Buenos Aires: Astrea, $7^{\circ}$ Ed., 1995, p. 550; STRATENWERTH, Derecho Penal, cit. nota n ${ }^{\circ}$ 25, p. 453; JESCHECK/WEIGEND, Tratado, cit. nota $\mathrm{n}^{\circ}$ 23, p. 788; von Beling refiere al "especial valor delictivo", en VON BELING, Ernst, Esquema de derecho penal. La doctrina del delito-tipo, Trad.: SOLER, Sebastián, Buenos Aires: El Foro, 2002, p. 169; Merkel habla de un solo delito, el cual, por sus caracteres, puede ser sometido a diferentes leyes "entre las cuales exista una porfía aparente por apoderarse del hecho", en: MERKEL, Derecho, cit. nota n ${ }^{\circ}$ 1, p. 379; Frister hace referencia a que la condena por uno de los tipos abarca el ilícito de todos (FRISTER, Derecho penal, cit. nota ${ }^{\circ}$ 28, p. 679); MIR, Derecho Penal, cit. nota $n^{\circ}$ 53, p. 662; Para Welzel, el contenido delictual de una acción es determinado en forma exhaustiva por un solo tipo penal, WELZEL, Derecho penal, cit. nota $n^{\circ} 14$, p. 228; Mezger indica que "en verdad, uno de los puntos de vista jurídicos es consumido totalmente por el otro" (MEZGER, Edmund, Tratado de Derecho Penal. Tomo II, Trad.: RODRIGUEZ, José, Madrid, Editorial revista de derecho privado, $2^{\circ}$ Ed., 1957, p. 380). Mayer no hace referencia al contenido de ilicitud, sino que a un problema de interpretación (MAYER, Max Ernst, Derecho Penal. Parte General, Trad.: POLITOFF, Sergio, Montevideo-Buenos Aires, B de f, 2007, p. 621); también refiriendo a la interpretación SANZ MORÁN, Ángel José, "Concurso de delitos en la reforma penal", en CALDERÓN CEREZO, Ángel: Cuadernos de derecho judicial, unidad y pluralidad de delitos, Madrid, Consejo General del Poder Judicial, 1995, pp. 190 y ss., hace referencia a una visión interpretativa del concurso aparente, en que se busca evitar el non bis in idem.

${ }^{59}$ MIR, Derecho Penal, cit. nota $n^{\circ}$ 53, p. 663; FRISTER, Derecho penal, cit. nota ${ }^{\circ} 28$, pp. 682 a 687; JESCHECK; WEIGEND, Tratado, cit. nota ${ }^{\circ} 23$, pp. 790 a 792.

${ }^{60}$ MEZGER, Tratado. Tomo II, cit. nota ${ }^{\circ} 58$, p. 381.

${ }^{61}$ Por ejemplo: STRATENWERTH, Derecho Penal, cit. nota ${ }^{\circ} 25$, p. 454.

${ }^{62}$ MAYER, Derecho Penal, cit. nota ${ }^{\circ}$ 58, p. 622; JESCHECK/WEIGEND, Tratado, cit. nota ${ }^{\circ} 23$, p. 790.

${ }^{63}$ MATUS, "Los criterios", cit. nota n ${ }^{\circ} 53$, p. 466.

${ }^{64}$ MAURACH/GÖSSEL/ZIPF, Parte General II, cit. nota n ${ }^{\circ}$ 58, p. 555.
} 
desde el delito de peligro al delito de daño, ${ }^{65}$ lesiones y homicidio ${ }^{66}$ sino que también se ha incluido en ella a relaciones entre diversas formas de imputación, como en el paso desde la participación a la autoría, desde la tentativa a la consumación ${ }^{67}$ o desde la acción imprudente a la dolosa. ${ }^{68}$

Finalmente, la consunción descansa en la consideración por parte del legislador de la realidad en que aparece la criminalidad, ${ }^{69}$ en la cual habría una relación contingente entre tipos penales conforme a la cual uno de ellos resulta accesorio al otro, ya sea porque lo acompaña normalmente, porque tiene lugar para materializar el beneficio por el cual se realizó el acto principal ${ }^{70}$ o porque su contenido de ilicitud es insignificante en relación con el otro; ${ }^{71}$ incluyéndose como casos de consunción, típicamente los supuestos de hechos anteriores, coetáneos y posteriores co-penados.

Este modelo, si bien parece generalizado, en ningún caso es unánime. Así, y sólo a modo puramente ejemplar, mientras que Mezger agrupaba todos los casos únicamente en dos principios (especialidad y "precedencia valorativa"), Stratenwerth distingue entre casos de consunción, supuesto en que un tipo acompaña normalmente la ejecución de otro; y el hecho posterior impune, en que el hecho de aseguramiento de un delito principal queda absorbido por éste, en la medida que -por no generar un daño nuevo ni afectar un bien jurídico distinto- no contiene un peso delictual autónomo. ${ }^{72}$ Matus, uno de los autores nacionales que con mayor seriedad ha estudiado la materia, afirma que la definición del concurso aparente referida a la comprensión total del disvalor de la acción en un único tipo resulta errada, no pudiendo explicar adecuadamente los casos de especialidad en que se sanciona únicamente por el tipo privilegiado. ${ }^{73}$ Por ello propone agrupar los principios de solución bajo dos categorías: los que se explican por ser manifestación del principio de non bis in idem, lo que ocurriría en los casos de especialidad, subsidiaridad y alternatividad ${ }^{74}$ y los que se justifican bajo el principio de insignificancia, el cual manifestaría, a su vez, la solución otorgada por el principio de consunción, referido a casos en que hay una relación empírica entre los hechos analizados, incluyendo en este supuesto las hipótesis de formas subsidiarias de imputación. ${ }^{75}$

\footnotetext{
${ }^{65}$ FRISTER, Derecho penal, cit. nota $\mathrm{n}^{\circ} 28$, pp. 685,

${ }^{66}$ MATUS, Jean Pierre, "La teoría del concurso (aparente) de leyes en la dogmática alemana, desde sus orígenes hasta el presente (Primera parte)”, Ius et Praxis, Vol. 6, n 2 (2000), p. 313.

${ }^{67}$ JESCHECK/WEIGEND, Tratado, cit. nota ${ }^{\circ} 23$, p. 792.

${ }^{68}$ MIR, Derecho Penal, cit. nota ${ }^{\circ} 53$, p. 663.

${ }^{69}$ FRISTER, Derecho penal, cit. nota $\mathrm{n}^{\circ} 28$, p. 686.

${ }^{70}$ JESCHECK/WEIGEND, Tratado, cit. nota $\mathrm{n}^{\circ}$ 23, p. 793.

${ }^{71}$ FRISTER, Derecho penal, cit. nota n ${ }^{\circ}$ 28, p. 686; MIR, Derecho Penal, cit. nota n ${ }^{\circ}$ 53, p. 667.

${ }^{72}$ STRATENWERTH, Derecho Penal, cit. nota ${ }^{\circ} 25$, pp. 455 y 457.

${ }^{73}$ MATUS, "Los criterios", cit. nota n ${ }^{\circ}$ 53, p. 468.

${ }^{74}$ MATUS, "Los criterios", cit. nota n ${ }^{\circ} 53$, pp. 466 y 481 y ss.

${ }^{75}$ MATUS, "Los criterios", cit. nota ${ }^{\circ}$ 53, pp. 483 y ss.
} 
2.1.1. Concurso aparente desde la prevención: especialidad como reiteración “formal”.

Desde una aproximación preventiva que parta de las ideas originales de von Liszt, el tratamiento de los casos de especialidad deberá ser, efectivamente, la aplicación de la pena del único delito absorbente. Y no podría ser de otra manera, por cuanto en estos casos el concurso tiene un origen puramente formal, es decir, independiente de cualquier consideración de las particularidades del caso en concreto: ya de la pura lectura de la ley es posible advertir el concurso. Por ello, la circunstancia de que en quien en la práctica mata a su madre, también verifica el supuesto de hecho del homicidio, no agrega nada que no sepamos ya respecto de la personalidad libre del autor. ${ }^{76}$

Así, en la medida que se busca adecuar la pena a la resocialización del delincuente, el delito se va desjuridificando, ${ }^{77}$ y con ello, la unidad de acción relevante no puede ser la jurídica, sino que debe producirse un acercamiento hacia la el sentido natural de acción, con lo que la multiplicidad de infracciones formales a normas de comportamiento deviene en irrelevante, ya que una vez afirmado que ha habido delito, el análisis dogmático queda de lado, ${ }^{78}$ puesto que la pena no reacciona para hacer frente a infracciones normativas, sino que para proteger a la sociedad.

Ello se expresa con claridad al afirmar que el delito corresponde a una realidad que no es captada adecuadamente por el derecho, sino que debe ser considerado de una manera más holística que permita dar luz sobre las particularidades del delincuente; ${ }^{79}$ y si el concurso por especialidad se puede identificar incluso antes de que el delito se haya realizado, entonces no puede tener incidencia en la pena.

Ahora bien, así como la antinormatividad formal de una conducta carece de incidencia para la determinación del tratamiento del concurso aparente; el daño material que ella ha causado tampoco es inmediatamente relevante, sino sólo en tanto indicador de necesidades preventivas; ya que independiente de si el hecho se aprecia en tanto infracción a una norma de conducta, o como lesión material de bienes jurídicos, la prevención especial no pena para el hecho cometido, sino que sólo con motivo de aquel. ${ }^{80}$ Por ello, el que en los casos de consunción el delito accesorio no agregue mayor contenido de ilicitud, ni afecte nuevos bienes jurídicos, no significa que su ocurrencia sea irrelevante. Al contrario, puesto que se trata de hechos que no tienen lugar necesariamente cada vez que se realiza el hecho principal, su ocurrencia en el caso concreto puede servir como indicador respecto de la personalidad del autor.

\footnotetext{
${ }^{76}$ BERISTAIN, Antonio, "Estructura e ideología de la nueva defensa social”, ADPCP, Tomo 14, n 3 (1961), p. 417.

${ }_{77}$ MUÑAGORRI, Ignacio, Sanción penal y política criminal. Confrontación con la nueva defensa social, Madrid: Reus, 1977, p. 21

${ }^{78}$ ZYSMAN, Diego, Sociología del castigo. Genealogía de la determinación de la pena. Buenos Aires: Didot, 2012, p. 172.

${ }^{79}$ BERISTAIN, "Estructura", cit. nota n 76 , pp. 418 a 420.

${ }^{80}$ VON BELING, Esquema, cit. nota n ${ }^{\circ} 58$, p. 23.
} 
Polít. crim. Vol. 8, № 16 (Diciembre 2013), Art. 5, pp. 500 - 543.

[http://www.politicacriminal.cl/Vol_08/n_16/Vol8N16A5.pdf]

Para aclarar esto, nuevamente es necesario aproximarse desde la distinción entre unidad y pluralidad de acciones. En los casos de concurso aparente por consunción, al igual que en los casos de subsidiaridad definidos por el paso desde la participación a la autoría, o desde una tentativa previa fracasada a una consumación, es posible observar una multiplicidad de acciones en sentido natural: es decir, la reiteración no está dada por una consideración meramente formal, sino que al contrario, son juicios normativos los que determinan la unificación de lo que "socialmente" podría ser advertido como una pluralidad. Así, en los casos de subsidiaridad señalados hay unidad jurídica de acción sustentada en la realización sucesiva del tipo, pero no obstante ello, seguimos viendo dos acciones independientes en sentido natural, constitutivas de diversas "expresiones de voluntad", 81 antecedentes que pueden ser relevantes para analizar la conciencia e intención del agente ${ }^{82}$ o los rasgos de comportamiento psicosocial del individuo. ${ }^{83}$ Más aún, en los casos de concurso aparente por consunción de los actos co-penados, ni siquiera es posible afirmar la unidad jurídica de acción, habiendo, por el contrario, necesariamente una pluralidad de acciones desde una apreciación social de los eventos.

\subsubsection{Concurso aparente desde la prevención: reiteración de acciones en sentido natural.}

Ahora bien, esa reiteración de conductas puede ser leída, preventivo-especialmente, de distintas maneras.

En von Liszt, la reiteración delictiva es expresiva, en general, de habitualidad, la cual caracteriza a los delincuentes irrecuperables, es decir, a aquellos respecto de los cuales las necesidades preventivo-especiales son más intensas, correspondiendo reaccionar ante ellos mediante la pena perpetua. ${ }^{84}$ De manera similar, Mayer afirma que la reincidencia es un síntoma de la habitualidad, ${ }^{85}$ y ésta, determina que el sujeto deba ser objeto de "medidas de utilidad sin carácter punitivo", o medidas de seguridad, ${ }^{86}$ es decir, recibir un trato de marcado carácter preventivo especial. Igualmente, Welzel explica que la repetición es uno de los factores que condicionan la categorización del autor como un delincuente consuetudinario peligroso, ${ }^{87}$ agregando que la habitualidad delictiva conlleva el abandono del derecho penal protector de valores ético-sociales y su reemplazo por un derecho penal preventivo especial. $^{88}$

Ello indicaría que en principio, es posible afirmar una relación positiva entre reiteración y necesidades preventivas. Pero ello no es siempre así. Von Liszt señala que la mayoría de los delincuentes son reincidentes, y la mayoría de los reincidentes son irrecuperables (habituales), pero es posible encontrar reincidentes recuperables. ${ }^{89}$ Ello se condice con la

\footnotetext{
${ }^{81}$ JESCHECK/WEIGEND, Tratado, cit. nota $\mathrm{n}^{\circ}$ 23, p. 764.

${ }^{82}$ JIMÉNEZ DE ASÚA, El criminalista, cit. nota n ${ }^{\circ} 20$, p. 12.

${ }^{83}$ BERISTAIN, "Estructura", cit. nota ${ }^{\circ} 76$, p. 417.

${ }^{84}$ VON LISZT, La idea, cit. nota ${ }^{\circ} 17$, pp. 116 y ss.

${ }^{85}$ MAYER, Derecho Penal, cit. nota n ${ }^{\circ}$ 58, p. 597.

${ }^{86}$ MAYER, Derecho Penal, cit. nota n ${ }^{\circ} 58$, p. 544.

${ }^{87}$ WELZEL, Derecho penal, cit. nota ${ }^{\circ} 14$, p. 252.

${ }^{88}$ WELZEL, Derecho penal, cit. nota $\mathrm{n}^{\circ} 14$, pp. 11 y ss.

${ }^{89}$ VON LISZT, La idea, cit. nota $\mathrm{n}^{\circ} 17$, p. 123.
} 
afirmación de Mezger, en el sentido que la reincidencia constituye un factor que, si bien agrava la culpabilidad, no necesariamente supone un síntoma de peligrosidad. ${ }^{90}$ La misma idea se puede encontrar en Mayer, al señalar que la habitualidad no va necesariamente encadenada a la multiplicidad de acciones, sino que puede expresarse la habitualidad incluso en la ejecución de un hecho aislado. ${ }^{91}$ En definitiva, la reiteración no constituye ni condición necesaria ni suficiente de habitualidad, pero si será un indicio de ella, la que a su vez, por motivos de prevención especial, exigirá un trato más severo. Entonces, para efectuar ese análisis más fino que permita distinguir los casos en que la reiteración -por constituir un indicativo de mayores necesidades preventivas- efectivamente debe tener consecuencias agravatorias de la pena, es necesario atender a las relaciones que se puedan establecer entre los delitos cometidos. Así, Merkel afirma que tratándose de delitos de una misma especie, la reiteración debe ser entendida como manifestación de una debilidad ante cierto tipo de estímulos que impide resistir al delito, lo cual redunda en que la forma correcta de tratar al sujeto no es mediante una agravación de la pena, sino que organizando su ejecución como una tentativa de reforma que vaya acompañada de medidas de policía. ${ }^{92}$ Para Mayer, por su lado, en la medida que la reiteración se explique por la debilidad del carácter del sujeto, quien no tiene fuerzas para resistirse a una misma oportunidad que se le presenta reiteradas veces, entonces el juicio con él debe ser menos riguroso. ${ }^{93}$

Si esto es así, entonces es posible ofrecer una explicación prevencionista del tratamiento privilegiado del concurso aparente en casos de consunción y de subsidiaridad por realización sucesiva del tipo: en ellos, habrá reiteración delictiva en tanto que se habrán realizado múltiples acciones en sentido natural, pero todas ellas se encontrarán relacionadas en función de un delito principal. Esa relación impediría afirmar que la pluralidad es expresiva de habitualidad, sino que por el contrario, estaría escondiendo que todas esas acciones naturales se pueden reconducir a una única resolución delictiva originada en un mismo propósito y motivo. ${ }^{94}$ Esta misma unidad sería posible de encontrar en los supuestos de concurso medial. En este caso, nuevamente nos encontrarnos con una pluralidad de acciones delictivas en sentido natural explicadas todas por una unidad a nivel subjetivo.

\subsubsection{Excurso: Relación entre culpabilidad y prevención.}

Ahora bien, aún cuando esa menor peligrosidad del sujeto no equivale a afirmar una menor culpabilidad, la estructura que ésta última tiene en las concepciones anticuadas, sí permite establecer una serie de puntos de contacto que serán relevantes si se quiere explicar desde las teorías actuales el tratamiento que se le da al hito de la reiteración. Así, si bien Welzel afirma que la condición de delincuente habitual no supone un compromiso con una afirmación de mayor culpabilidad, ya que esa tendencia peligrosa puede ser tanto culpablemente adquirida (caso en el cual la agravación de la pena responderá a razones

\footnotetext{
${ }^{90}$ MEZGER, Tratado. Tomo II, cit. nota ${ }^{\circ}$ 58, p. 121; MEZGER, Edmund, Derecho penal. Libro de estudio. Parte general, Buenos Aires: Editorial Bibliográfica Argentina, 1958, p. 242.

${ }^{91}$ MAYER, Derecho Penal, cit. nota n ${ }^{\circ} 58$, p. 214.

${ }^{92}$ MERKEL, Derecho, cit. nota ${ }^{\circ} 1$, pp. 374 y 375.

${ }^{93}$ MAYER, Derecho Penal, cit. nota ${ }^{\circ} 58$, p. 213.

${ }^{94}$ MAYER, Derecho Penal, cit. nota n ${ }^{\circ}$ 58, pp. 201 a 203.
} 
retributivas) como originada en factores naturales (caso en el que la agravación constituirá una medida de seguridad) ${ }^{95}$ la verdad es que la concepción personalizada de la culpabilidad que se defiende hace fácil la inclusión de consideraciones preventivas en su determinación. Se trata de una culpabilidad por conducción de vida, en que se considera la depravación de la personalidad del autor y su habituación a costumbres corruptas. Luego, no considera la "posibilidad de actuar de otro modo", sino que el autor es culpable de su modo de ser, de forma tal que pasan a ser plenamente relevantes los hechos penales cometidos anteriormente. ${ }^{96}$

Así, si volvemos al trabajo de von Liszt, veremos que la especificación de la pena según las posibilidades y necesidades de corrección del delincuente, lo llevan a afirmar que la única pena retributiva es la pena protectora; por lo que a la pregunta por el merecimiento del autor se responde teleológicamente: "se merece lo que es adecuado al autor", lográndose de esa forma prevención mediante retribución. ${ }^{97}$ Con ello, von Liszt está recurriendo a consideraciones prevencionistas para afirmar que no es procedente la retribución ante hechos cometidos en un acto de locura o que se explican por caprichos de la causalidad, con lo que se traba una relación entre el concepto de culpabilidad y el juicio de peligrosidad propio de la prevención especial.

Algo similar ocurre con la teoría de la culpabilidad de Merkel, la cual se aboca a la pregunta de si acaso la "actividad violadora de los intereses sociales y de las normas jurídicas, debe ser referida a la voluntad de un hombre, esto es, si la actividad tiene su causa adecuada en la afirmación de la individualidad de éste". ${ }^{98}$ En función de ello, se sostiene que las acciones y el carácter no se hallan entre sí en una relación meramente accidental, sino que más bien, este último se revela y manifiesta en aquellas, y ello permite dar un sentido racional al enlace entre la valoración de un hecho y la personalidad del autor. ${ }^{99}$ Ello significa que los mismos elementos que son relevantes para la determinación de la culpabilidad, son los que se deben tomar en cuenta para cumplir las finalidades preventivoespeciales. Por ejemplo, la "debilidad de carácter", de sus "condiciones y dotes espirituales" y la "poca fuerza para resistir al delito", son todas consideraciones que inciden en la culpabilidad, y que a la vez deben ser tomadas en cuenta al momento de definir una reacción estatal particularizada para ese tipo de delincuente. ${ }^{100}$

De esta forma, también Mayer recurre en el análisis de la culpabilidad al carácter del autor, ya que si bien entiende la culpabilidad como referida a la infracción de deber que produce un resultado, centrándose en los motivos del agente, ${ }^{101}$ y critica la personalización de la culpabilidad y su influencia en la determinación de la pena preventivo especial, indicando

\footnotetext{
${ }^{95}$ WELZEL, Derecho penal, cit. nota ${ }^{\circ} 14$, pp. 255 y 256.

${ }^{96}$ DEMETRIO CRESPO, Eduardo, Prevención general e individualización judicial de la pena, Salamanca: Ediciones Universidad de Salamanca, 1999, p. 227.

${ }^{97}$ VON LISZT, La idea, cit. nota ${ }^{\circ} 17$, p. 130.

${ }^{98}$ MERKEL, Derecho, cit. nota n ${ }^{\circ} 1$, pp. 103 y 104.

${ }^{99}$ MERKEL, Derecho, cit. nota ${ }^{\circ} 1$, p. 105.

${ }^{100}$ MERKEL, Derecho, cit. nota ${ }^{\circ} 1$, pp. 373 y ss.

${ }^{101}$ MAYER, Derecho Penal, cit. nota n ${ }^{\circ} 58$, pp. 288 y 299.
} 
que con ello se altera la medida de la culpabilidad para lograr una proporcionalidad con la pena; ${ }^{102}$ igualmente señala que en la concreción de la amenaza penal el tribunal bien puede considerar la personalidad del autor, ${ }^{103}$ agregando que es importante determinar si "la conducta del autor obedece más a su carácter o más a circunstancias externas", ${ }^{104}$ y especifica que lo más relevante es la toma de posición del autor frente a su deber, y que esa determinación sólo se puede realizar analizando la totalidad de la espiritualidad del autor y de sus facultades espirituales, por lo que el comportamiento es más condenable si él expresa la esencia del autor. ${ }^{105}$ Por otro lado, Mezger afirma en términos explícitos que la pena debe graduarse de conformidad a la culpabilidad del autor, la cual se configura en consideración a su personalidad; ${ }^{106}$ y es esa misma personalidad la que deberá ser tomada en consideración a efecto de adecuar la pena a las exigencias preventivo-especiales perseguidas. ${ }^{107}$ Más aún, en el Tratado de Jescheck se hace referencia a la reprochabilidad de la actitud interna del autor como una de las tres variables de las que depende el merecimiento de pena. ${ }^{108}$ Así, a propósito del objeto del juicio de culpabilidad, se afirma que éste recae en el hecho antijurídico realizado, por cuanto aquel "actualiza la actitud interna jurídicamente desaprobada del autor", por lo que la culpabilidad tiene lugar cuando la formación de voluntad del sujeto descansa en una "actitud interna deficiente". ${ }^{109}$ Es decir, el hecho delictual es un indicador de la culpabilidad material del sujeto, la cual es dependiente directamente de su actitud interna.

Así, cuando se predica la habitualidad respecto de un delincuente, ello no sólo parece hacer referencia a las necesidades preventivo especiales, sino que en algunos casos también corresponderá a un juicio sobre su culpabilidad. Esto parece ser especialmente claro en Mayer, quien argumenta que no toda reincidencia supone mayor culpabilidad, justamente porque es posible que la reincidencia no fundamente habitualidad, y está sí va unida a un mayor reproche. ${ }^{110}$ Esta superposición categorial fue abordada por Antolisei quien señala que el juicio de peligrosidad, relevante a efectos preventivo-especiales, no puede considerarse independiente de la voluntad del autor, ya que aquel depende de sus acciones, correspondiendo a un estado antijurídico voluntariamente adquirido. ${ }^{11}$ Ello, como indicaba von Liszt, sirve para superar la tensión entre retribución de culpabilidad y prevención especial: ante varios hechos que se explican por un mismo estado subjetivo, corresponde una pena atenuada tanto por haber una menor culpabilidad que reprochar, como por haber menor peligrosidad ante la cual intervenir.

\footnotetext{
${ }^{102}$ MAYER, Derecho Penal, cit. nota $n^{\circ} 58$, p. 539, nota al pie $\mathrm{n}^{\circ} 31$. Agregando que es en la medida de seguridad, y no en la pena, donde la personalidad del autor es fundamental (p. 546).

${ }^{103}$ MAYER, Derecho Penal, cit. nota n ${ }^{\circ} 58$, p. 602.

${ }^{104}$ MAYER, Derecho Penal, cit. nota n ${ }^{\circ}$ 58, p. 310.

${ }^{105}$ MAYER, Derecho Penal, cit. nota ${ }^{\circ}$ 58, p. 613

${ }^{106}$ MEZGER, Tratado. Tomo II, cit. nota n ${ }^{\circ} 58$, pp. 425 y 426.

${ }^{107}$ MEZGER, Tratado. Tomo II, cit. nota n ${ }^{\circ} 58$, pp. 432 y 433.

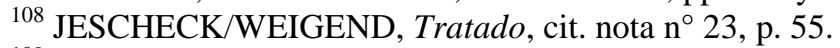

${ }^{109}$ JESCHECK/WEIGEND, Tratado, cit. nota n $^{\circ} 23$, pp. 456 y 457.

${ }^{110}$ MAYER, Derecho Penal, cit. nota n ${ }^{\circ}$ 58, p. 597.

${ }^{111}$ ANTOLISEI, Francesco, Manual de derecho penal. Parte general, Trad.: GUERRERO, Jorge; AYERRA, Marino, Bogotá, Temis, $8^{\circ}$ Ed., 1988, p. 467.
} 


\section{Polít. crim. Vol. 8, № 16 (Diciembre 2013), Art. 5, pp. 500 - 543. [http://www.politicacriminal.cl/Vol_08/n_16/Vol8N16A5.pdf]}

Siendo esto así, se esperaría que un cambio en el entendimiento de la culpabilidad supusiera una valoración diversa de los casos de consunción y subsidiaridad por realización sucesiva. Pero, como se verá, ello no necesariamente ocurre.

Las concepciones la culpabilidad en los casos anteriormente citados se habían funcionalizado a favor de consideraciones preventivo especiales. Ello constituye un proceso similar a la funcionalización de la culpabilidad que propone Roxin y que es maximizado por Jakobs en su teoría funcional de la pena. ${ }^{112}$ Así, en la teoría del delito se deja de lado una concepción personalizada o psicológica de la culpabilidad, y con Welzel ella pasa a estar constituida por la posibilidad de reprochar la acción injusta al autor, ${ }^{113}$ lo que dependerá de que se hayan dado en el caso concreto las condiciones bajo las cuales es posible entender que el éste pudo haberse comportado de conformidad a las exigencias del derecho. ${ }^{114}$ Luego, con el intento de Roxin por compaginar política criminal con dogmática -favoreciendo que las valoraciones de la primera penetren en el sistema de la segunda, para que esta última sea sensible a la "realidad social",$-{ }^{115}$ el principio de culpabilidad se ve complementado con consideraciones preventivo generales referidas a las circunstancias personales o situacionales en las cuales - habiendo posibilidad de actuar conforme a derecho- no es indispensable la reacción penal. ${ }^{116}$

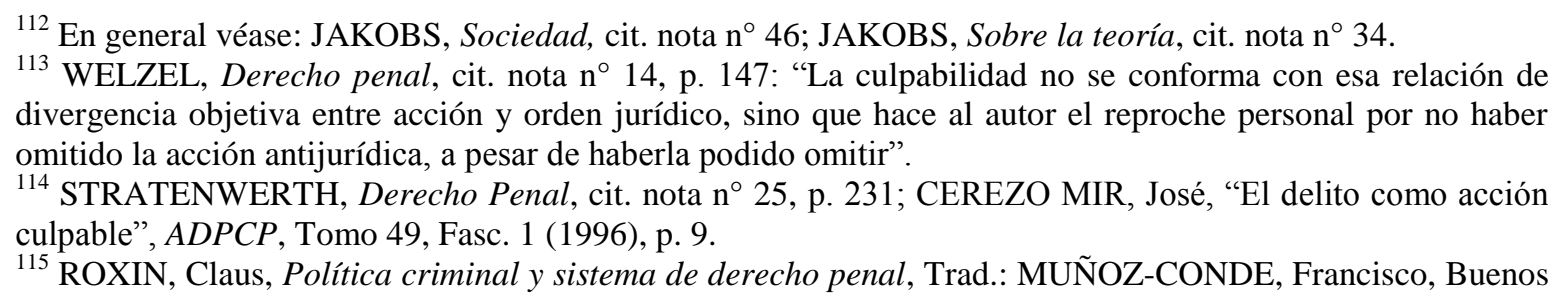
Aires: Hammurabi, $2^{\circ}$ ed., 2002, p. 52, concluyendo entonces que derecho penal es la forma en la que las finalidades político-criminales se transforman en módulos de vigencia jurídica (p. 101).

${ }^{116}$ ROXIN, Política criminal, cit. nota $\mathrm{n}^{\circ} 115$, p. 59. Luego, en el esquema de Jakobs, ya no se trata de una complementación de la culpabilidad, sino que una redefinición completa de la misma, por cuanto la culpabilidad se concibe en términos puramente prevencionistas, en que ella simplemente constituye las condiciones bajo las cuales la conducta realizada tiene sentido comunicativamente, de forma tal que en ausencia de culpabilidad, la conducta injusta carece de sentido ya que aquella no ha sido expresión de comunicación de una persona, sino que es vista como pura naturaleza -una enfermedad, un erro inevitable o miedo-, distinción que depende finalmente de condiciones determinadas socialmente (JAKOBS, Sociedad, cit. nota $\mathrm{n}^{\circ}$ 46, pp. 60 a 67). Luego, habiendo culpabilidad, entonces resulta necesaria la pena para marginar el significado comunicativo del hecho (JAKOBS, Günther, Fundamentos del derecho penal, Trad: CANCIO MELIÁ, Manuel; PEÑARANDA RAMOS, Enrique, Buenos Aires: Editorial Ad-Hoc, 1996, pp. 114 y ss.), denominándose "culpabilidad" a la suma de factores que determinan que la asimilación de esa conducta requiere de una reacción formalizada como lo es la pena (JAKOBS, Sociedad, cit. nota ${ }^{\circ} 46$, p. 32), de forma tal que la culpabilidad es expresiva de esas necesidades (SILVA SÁNCHEZ, Jesús, El nuevo código penal: cinco cuestiones fundamentales, Barcelona: Bosch, 1997, p. 28). Con ello, se afirma que "culpabilidad" corresponde a la denominación de la suma de factores que determinan que la asimilación de esa conducta requiere de una reacción formalizada como lo es la pena (JAKOBS, Sociedad, cit. nota $\mathrm{n}^{\circ} 46$, p. 32). Si ello es así, se traba una relación lógica entre la culpabilidad y una teoría de la pena con finalidades relativas al aseguramiento de la vigencia de la norma contrafácticamente (SILVA SÁNCHEZ, El nuevo código, p. 34): ante la contradicción entre la persona y la obligatoriedad de una institución, la sociedad debe contar con un mecanismo que evite la erosión de la identidad normativa derivada de la infracción a la norma, infracción que es entendida como comunicación defectuosa. De lo contrario, toda divergencia será tomada como inicio de evolución social: en caso de no responderse a la defraudación, decrecerá la confianza en la norma y ella dejará 
A pesar de esta nueva concepción de la culpabilidad, que en la teoría de la unión sirve para limitar la persecución de fines preventivo-especiales, igualmente es posible con esa estructura mantener la misma valoración de los supuestos de concurso aparente que se realizaba en base a una teoría puramente prevencionista y no limitada por consideraciones al principio de culpabilidad. La explicación de esto se encuentra en el notable trabajo de Hörnle sobre la supervivencia de la teoría anticuada de la culpabilidad en la determinación de la pena. ${ }^{117}$

En principio, conforme a la teoría del espacio de juego, la medición de la pena debe afirmarse en consideración a la culpabilidad del autor. ${ }^{118}$ Y ella, en la actualidad, constituye un criterio formal, que no dice relación con consideraciones independientes del hecho cometido, ni se encuentra referida a la personalidad o actitudes del delincuente. ${ }^{119}$ Pero, en el marco de la determinación de la pena, y como bien lo explica Jescheck, el derecho penal vigente sigue tomando en cuenta la personalidad del autor. ${ }^{120}$ En ese sentido, le asiente razón a Ziffer cuando afirma que la culpabilidad que se toma en consideración a efectos de determinar la pena es "más amplia" que la utilizada en la actual teoría del delito. ${ }^{121} \mathrm{Y}$ es que justamente, en una concepción anticuada de la culpabilidad (en los términos de Hörnle), el delito sólo es una manifestación de esa culpabilidad en tanto carácter defectuoso; mientras que actualmente la culpabilidad constituye un criterio que sirve para determinar en qué medida el hecho delictual puede imputársele a su autor. ${ }^{122}$

Eso significa que las mismas consideraciones caracterológicas que antes -en las teorías de la prevención especial- permitían afirmar que la realización de hechos delictivos relacionados era un indicio de baja peligrosidad, ya que se podían explicar todas las acciones recurriendo a una única resolución delictiva y a un mismo propósito y motivo, lo cual se traducía en menores necesidades preventivo-especiales; ahora también pueden servir para explicar una atenuación de la pena, pero ya no en función de que el sujeto ofrezca mayores garantías cognitivas.

Y es que la trascendental importancia que se le asigna a la categoría de delincuente habitual se explica en un marco teórico dominado por el análisis sociológico de la delincuencia, ${ }^{123}$ en que la aproximación al delito se basa en el estudio y análisis social del delito y la pena, ${ }^{124}$ para lo cual se recurre al estudio de los mejores métodos de lucha contra la

de ser entendida como vinculante (FEIJOO SÁNCHEZ, Bernardo, El injusto penal y su prevención ante el nuevo código penal de 1995, Madrid: Editorial Colex, 1997, p. 58).

117 HÖRNLE, Tatjana, "La concepción anticuada de la culpabilidad en la jurisprudencia y doctrina tradicionales de la medición de la pena", Trad.: MARTín LORENZO, María, ADPCP, Vol. LIV (2001).

${ }^{118}$ HÖRNLE, "La concepción anticuada", cit. nota n ${ }^{\circ} 117$, p. 406.

${ }^{119}$ HÖRNLE, "La concepción anticuada", cit. nota n 117, p. 412.

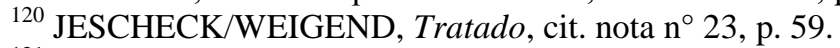

${ }^{121}$ ZIFFER, Lineamientos, cit. nota ${ }^{\circ} 30$, p. 91.

${ }^{122}$ HÖRNLE, "La concepción anticuada", cit. nota n 117, p. 414.

${ }^{123}$ VON LISZT, La idea, cit. nota ${ }^{\circ} 17$, p. 106.

${ }^{124}$ MAYER, Derecho Penal, cit. nota n ${ }^{\circ}$ 58, p. 531. 


\section{Polít. crim. Vol. 8, № 16 (Diciembre 2013), Art. 5, pp. 500 - 543. [http://www.politicacriminal.cl/Vol_08/n_16/Vol8N16A5.pdf]}

criminalidad, inspirándose en los resultados de las ciencias del hombre, ${ }^{125}$ y alejándose de consideraciones teóricas o de ciencia pura que carecen de relevancia práctica o valor verdadero. $^{126}$

Luego, en la medida que estas aproximaciones dejan de tener la relevancia en la dogmática penal que tenía en el positivismo, resulta que el hecho de que la reiteración obedezca a una unidad de resolución delictiva no debería tener la incidencia en el análisis preventivo especial que poseía en la época de von Liszt. Por ello, el trato beneficioso en estos casos debería explicarse primordialmente por comprender que esa unidad de motivo constituye un indicio de una menor culpabilidad ${ }^{127}$ entendida en los términos anticuados, la cual estará -en el marco de la teoría de la unión- justamente cumpliendo su función de reducir la magnitud de la reacción penal destinada al logro de finalidades preventivo especiales.

\subsubsection{Concurso aparente desde la retribución.}

A continuación se analizarán los distintos supuestos de concurso aparente, desde las dos perspectivas retributivas anteriormente estudiadas, por un lado la que retribuye acciones materialmente dañosas, y por otro, la que retribuye déficits de culpabilidad por falta de lealtad comunicativa.

\section{a) El concurso aparente y la retribución del daño.}

Desde una aproximación retributiva basada en el principio del daño, y al igual que desde una visión preventivo especial, el análisis relevante de las acciones debe realizarse desde una concepción de acción en sentido natural, ya que lo relevante es la determinación de la afectación que la víctima ha sufrido en su calidad de vida, y ese juicio no puede realizarse adecuadamente desde una perspectiva que ve la acción delictual sólo desde la perspectiva del la descripción típica.

Siendo ello así, los casos de concurso aparente por especialidad pareciera que se pueden explicar sin mayores dificultades: de manera similar que en el análisis desde la prevención especial, no hay nada que merezca mayor reproche, ya que si antes la pura reiteración formal era irrelevante a efectos de juzgar las necesidades preventivas del autor; ahora, esa pura duplicidad formal no puede agregar desde la perspectiva de la víctima un mayor daño.

Respecto de los hechos co-penados es posible realizar el mismo análisis. En la medida que la eximición de punibilidad se explique por cuanto el delito co-penado constituye sólo una acción que, sin agregar un daño nuevo, consiste en permitir "asegurar el beneficio del delito principal", ${ }^{128}$ ello no afectará la magnitud del daño infligido a la víctima. En esos casos, los

\footnotetext{
${ }^{125}$ BERISTAIN, "Estructura", cit. nota n ${ }^{\circ}$ 76, p. 414.

${ }^{126}$ ANCEL, Marc, "Penas y medidas de seguridad en el derecho positivo comparado", Trad.: MOSQUETE, Diego, Revista de derecho. Universidad de Concepción, $\mathrm{n}^{\circ}$ 99, año XXV (1957), p. 74. Por el contrario, Las concreciones penales necesitan, para tener existencia válida, las aportaciones de las ciencias humanas y sociales (MUÑAGORRI, Sanción penal, cit. nota n ${ }^{\circ} 77$, p. 22).

${ }^{127}$ HÖRNLE, "La concepción anticuada", cit. nota n ${ }^{\circ} 117$, p. 416.

${ }^{128}$ MIR, Derecho Penal, cit. nota n ${ }^{\circ}$ 53, p. 667.
} 
hechos posteriores, "en tanto no le irroguen al afectado un daño enteramente nuevo o no se dirijan contra un bien jurídico nuevo", no deberán ser considerados desde la perspectiva del afectado. $^{129}$ Lo mismo podría decirse de actos anteriores co-penados referidos al planeamiento del delito: Hörnle señala que la realización de un delito previo planeamiento detallado del mismo, no justificará, en la generalidad de los casos, un mayor reproche, por cuanto si esas acciones anteriores se realizan sin inmiscuirse en la esfera de la víctima, a ella no se le estará infligiendo una mal mayor; y entonces esa mayor energía criminal no debería tomarse en cuenta desde la perspectiva del daño. ${ }^{130}$

Distinto es el caso de los delitos consumidos por acompañar normalmente al principal, pero que sí generan un daño adicional, aún cuando aquel sea de menor magnitud. El caso típico es el de los daños que acompañan al robo. Es correcto afirmar que en estos casos el daño que experimenta la víctima no se explica por la pura destrucción de propiedad (como la rotura de un mueble), sino por el por el hecho de que los bienes "fueron vandalizados", saltando a la vista que ello genera un dolor distintivo: ese daño no obedece a un accidente, sino que a una injustica de la cual se ha sido víctima. ${ }^{131}$ Evidentemente la fractura es secundaria, pero ello no quita que ella genera un daño a la víctima (ello explica que se considerare como delito autónomo), y que por lo tanto aumenta lo reprochable de la conducta justificando una mayor pena. Si la explicación de la no punición se encuentra en que por acompañar normalmente al delito principal, el legislador ya los habría considerado en la regulación de aquel, ${ }^{132}$ y que por ello la pena asignada al delito absorvente expresa el reproche adecuado a ambos daños, entonces debería aceptarse que en los casos en que el daño menor no tenga lugar, la pena se viera disminuida, ya que el reproche penal se encuentra justificado sólo en la medida que sea proporcionado a lo materialmente censurable del acto, es decir, al daño ocasionado. ${ }^{133}$

En los casos de subsidiaridad, finalmente, habrá que distinguir. El paso desde la participación a la autoría no parecería relevante desde la perspectiva de la víctima, lo mismo que en el caso de acciones imprudentes previas a la comisión dolosa. En el caso de la transición desde el peligro al daño, la punición sólo por este último se podría explicar aduciendo que la justificación de los delitos de peligro tiene lugar en función de la relación de estos con un daño posible. Así, la legitimidad en base al principio del daño será más o menos débil dependiendo de la probabilidad de causar efectivamente un daño en caso de incumplir la norma; ${ }^{134}$ o, si el riesgo está dado por cuanto la conducta realizada facilita la realización de una conducta posterior efectivamente dañina, entonces la prohibición de esa

\footnotetext{
${ }^{129}$ STRATENWERTH, Derecho Penal, cit. nota ${ }^{\circ} 25$, p. 457.

${ }^{130}$ HÖRNLE, "Distribution", cit. nota n' 41, p. 199.

${ }^{131}$ DUFF, R. A., "Harms and wrongs", Buffalo Criminal Law Review n ${ }^{\circ} 13$ (2001-2002), p. 22

${ }_{132}$ MIR, Derecho Penal, cit. nota n ${ }^{\circ}$ 53, p. 666; STRATENWERTH, Derecho Penal, cit. nota ${ }^{\circ} 25$, p. 455.

${ }^{133}$ VON HIRSCH, Censurar y castigar, cit. nota ${ }^{\circ} 39$, pp. 26 y 28. En el mismo sentido: VON HIRSCH, "Proportionate sentences", cit. nota $\mathrm{n}^{\circ} 44$, p. 118: si la sanción expresa reproche, entonces la magnitud del castigo debe depender de lo condenable de la conducta, de forma tal que la desaprobación que comunica la sanción refleje lo reprensible de la acción.

${ }^{134}$ En el primer caso se está ante supuestos de peligro concreto, y en el segundo de peligro abstracto; en: SIMESTER, A. P.; VON HIRSCH, Andrew, "Remote harms and non-constitutive crimes", Criminal Justice Ethics, Vol. 28, n² 22, pp. 94 a 96.
} 


\section{Polít. crim. Vol. 8, № 16 (Diciembre 2013), Art. 5, pp. 500 - 543. [http://www.politicacriminal.cl/Vol_08/n_16/Vol8N16A5.pdf]}

conducta riesgosa no dañina también se derivaría de una extensión del principio del daño. ${ }^{135}$ Siendo ello así, los delitos de peligro no importarían una reprochabilidad independiente de daños eventuales, y ello explicaría que no fueran objeto de una sanción adicional a la que tiene lugar cuando esos daños sí se materializan.

Distinto es el caso de la tentativa anterior fracasada seguida de la consumación del delito; ya que es perfectamente posible suponer un caso en que la tentativa misma cause un daño adicional y relevante desde la perspectiva de la víctima, como ocurriría sin antes del disparo letal, se dan varios disparos que hieren dolorosamente al afectado.

\section{b) El concurso aparente y la retribución restablecedora.}

Si se analizan estos supuestos desde la teoría retributiva restablecedora, entonces la primera diferencia con que nos encontramos es que en este caso el concepto de acción relevante es justamente el de acción como unidad jurídica, ya que si la pena debe retribuir la infracción de la norma para restablecer su vigencia, entonces la acción no debe descansar en el punto de vista social según los usos normales de la vida, requiriéndose unidad de propósito y conexión espacio temporal; ${ }^{136}$ sino que debe definirse de forma tal que permita identificar las infracciones normativas.

Si se parte de esta premisa, entonces -en principio- quien mata dolosamente a su padre, gozando de capacidad de acción y de motivación, ${ }^{137}$ ha satisfecho el tipo penal del homicidio y del parricidio, siéndole imputable ordinariamente la infracción de ambas normas. ${ }^{138}$ Ahora bien, si la infracción imputable de la norma manifiesta un déficit de fidelidad que expresa el no haberla reconocido como razón excluyente para la acción, entonces ese déficit de fidelidad habrá sido manifestado en dos ocasiones, siendo procedente una doble sanción que restablezca ambas normas infringidas. Ello significaría que los supuestos de concurso aparente por especialidad deberían recibir doble pena.

Una forma de evitar este resultado podría explicarse al considerar que la norma de comportamiento debe ser comprendida como una razón para la acción, o en el caso del homicidio y el parricidio, para la abstención de la acción "matar". Si una razón operativa de primer orden es aquella que, simplemente, en caso de ser aceptada fundamenta una actitud crítica de desaliento hacia las creencias en conflicto y de aliento a las correspondientes; ${ }^{139}$ la norma jurídica no sólo tiene la pretensión de fundamentar esa actitud de desaliento a lo que contradice la abstención de "matar", sino que además busca constituirse en una razón

\footnotetext{
135 SIMESTER/VON HIRSCH, "Remote harms", cit. nota ${ }^{\circ} 134$, pp. 99 a 102.

${ }^{136}$ MIR, "Concurso de delitos", cit. nota ${ }^{\circ} 52$, p. 96.

${ }^{137}$ KINDHÄUSER, "La lógica", cit. nota ${ }^{\circ} 45$, pp. 7 y 8.

${ }^{138}$ HRUSCHKA, Joachim, "Reglas de comportamiento y reglas de imputación”, ADPCP, tomo XLVII, Fasc. III (1994), pp. 352 y ss. En general sobre la distinción entre imputación ordinaria y extraordinaria: EL MISMO, "La imputación ordinaria y extraordinaria en Pufendorf. Sobre la historia y el significado de la diferencia entre actio libera in se y actio libera in sua causa", Revista de derecho penal y criminología, 2. Época, $\mathrm{n}^{\circ} 12$ (2003), pp. 213 a 252.

${ }^{139}$ RAZ, Joseph, Razón práctica y normas. Trad.: RUIZ, Juan, Madrid: Centro de Estudios Constitucionales, $2^{\circ}$ Ed., 1991, pp. 36 y ss.
} 
para -respecto de la acción de matar- no considerar ninguna otra razón como relevante para la acción. En esa medida, la norma es una razón de primer orden para no realizar el acto normativo, y una razón excluyente de segundo orden para no actuar por otras razones en conflicto. ${ }^{140}$

Si ello es así, cada una de las normas de comportamiento cuyo supuesto ha sido verificado aspira a constituirse por sí sola, es decir, sin consideración a la otra, en razón para omitir la realización ambos supuestos: si el hijo hubiera sido fiel a la norma de conducta del tipo de parricidio, habría omitido la acción que realiza el supuesto de hecho de ambas, y puesto que cada norma aspira a constituirse en la única razón para esa omisión, entonces reprochar la infracción imputable de las dos normas resulta redundante, ya que es imposible actuar reconociendo simultáneamente a cada una de las normas como razón excluyente, ya que en tanto excluyentes- el seguimiento de cada norma exige omitir la acción por mor de seguir esa norma: ${ }^{141}$ lógicamente, entonces, si se reconoce el carácter de razón excluyente de la norma de parricidio, necesariamente no se estará reconociendo en esa calidad a la norma de homicidio; pero el reconocimiento de la norma de homicidio como razón excluyente no importa necesariamente un no seguimiento de la norma de parricidio, ya que ella no será aplicable a si a quien no se está matando es un tercero. Por ello, la sanción por la infracción imputable de la norma de parricidio expresaría la totalidad del reproche merecido.

Esta línea argumentativa no podría aducirse si se sigue la concepción de la norma que caracteriza a la teoría funcional de derecho penal, ya que en ella la norma no tiene un carácter imperativo, sino que ella cumpliría una función informativa sobre los "límites de actuación en la vida social"; ${ }^{142}$ y por ello no habría una superposición de mandatos que resultaría imposible seguir simultáneamente. Bajo esas condiciones, la no punición en los casos de especialidad deberá justificarse aduciendo que entre las normas en relación de especialidad hay una superposición en los contenidos mismos de las expectativas normativas, es decir, el comportamiento esperado en estos casos es uno sólo: no ser imputable ${ }^{143}$ por la muerte de otro, por lo que habría una única defraudación de expectativa, la cual sólo habría sido formalizada mediante dos disposiciones distintas. En los términos

${ }^{140}$ RAZ, Razón práctica, cit. nota n 139, p. 66.

${ }^{141}$ MAÑALICH, Juan Pablo, "Norma e imputación como categoría del hecho punible", REJ, n 12 (2010), p. 179.

${ }^{142}$ FEIJOO, Retribución, cit. nota n 36, p. 724.

${ }^{143}$ Dentro de este marco, la teoría de la imputación determinar cuándo una organización dada tiene como significado social el de desautorizar a la norma o defraudar una expectativa, lo que significa definir a una organización particular como causa determinante de un riesgo lesivo en desmedro de todas las demás -con lo que determina al mismo tiempo la existencia de una acción propiamente penal, ya que de faltar imputación el comportamiento solo será naturaleza-, requiriéndose infringir el rol que se ocupa (ya sea el genérico de "persona" o alguno especial del que se derivan deberes positivos). En este sentido, la teoría de la imputación se concibe como un esquema social de interpretación de conductas cuya configuración depende de la constitución de la sociedad; en: JAKOBS, Günther, Derecho penal. Parte general. Fundamentos y teoría de la imputación. Trad.: CUELLO CONTRERAS, Joaquín; SERRANO GONZALEZ DE MOURILLO, José Luís, Madrid: Marcial Pons Ediciones Jurídicas, 1997, p. 13; JAKOBS, Günther, La imputación objetiva en el derecho penal, Buenos Aires: Editorial Ad-Hoc, 1996, p. 15; y JAKOBS, Fundamentos, cit. nota n 116 , pp. 97 y 106. 


\section{Polít. crim. Vol. 8, № 16 (Diciembre 2013), Art. 5, pp. 500 - 543. [http://www.politicacriminal.cl/Vol_08/n_16/Vol8N16A5.pdf]}

del primer Jakobs, el comportamiento constituye un único delito, pero se ve abarcado por diversas formulaciones de delitos, las cuales varían en su grado de concreción. ${ }^{144}$ Siendo ello así, el restablecimiento de la vigencia de la expectativa "especial" importa necesariamente el restablecimiento de la vigencia de la expectativa general.

Respecto de los casos concurso aparente por subsidiaridad, en la medida que ellos hagan referencia a formas de imputación subsidiaria, la ausencia de punición debería explicarse a pesar de la contradicción efectiva que el comportamiento anterior ha significado para la norma: en la tentativa el comportamiento no exhibe todas las propiedades de la antinormatividad, pero se imputa como contradicción de norma si éste expresa una falta de reconocimiento a ella como razón para la acción. ${ }^{145}$ Así, si se siguiera la clasificación de los supuestos de concurso aparente que ofrece Matus, en la que se distingue entre supuestos explicados por el non bis in idem y otros por el principio de insignificancia, entonces la advertencia de este "contenido de ilicitud independiente" impide incluir los casos de imputación subsidiaria como supuestos de concurso aparente por subsidiaridad, ya que éstos se explican como una consecuencia del primer principio, conforme al cual, la opción por el concurso aparente debe tener lugar en caso que la aplicación del concurso ideal significara una doble apreciación de la misma propiedad jurídico-penalmente relevante; ${ }^{146}$ y en el caso de la tentativa previa fracasada, nos encontramos con una acción previa que ha expresado una "intensidad criminal" distinta de la que tiene lugar con la consumación, por lo que la duplicidad de sanción no se explicaría en valorar doblemente una misma propiedad relevante. Mientras que en esas condiciones Matus puede evadir la sanción argumentando la insignificancia de esa intensidad criminal, lo que explica la aplicación del principio de consunción; ${ }^{147}$ ello no parece ser suficiente para explicar la no punición desde una perspectiva retributiva restablecedora, ya que antes que una relación empírica entre las magnitudes de ilícito involucradas, la renuncia a la pena deberá explicarse por una relación jurídica entre las dos afectaciones a la vigencia de la norma que han tenido lugar.

Entonces, no pudiendo entenderse que la tentativa no ha afectado la vigencia de la norma, ni que esa afectación ha dejado de existir por la posterior consumación, la única razón por la cual no debería penarse independientemente la tentativa es entendiendo que la punición por el delito consumado posterior expresa todo el reproche merecido, y que la misma sirve como restablecimiento ante la afectación de vigencia que ha tenido lugar tanto por la consumación como por la tentativa. Es decir, la subsidiaridad se explica si la punición por la consumación restablece la perdida de vigencia que ha ocurrido tanto con ella y como con la tentativa. ${ }^{148}$ Ello significa que la tentativa fracasada efectivamente genera el derecho del Estado a sancionarla de manera independiente; pero que, en la medida que se sancione el delito consumado, esa sanción ya no es necesaria para el restablecimiento de la norma, y que por lo tanto, ese derecho no derivará en deber de sancionar. ${ }^{149}$

\footnotetext{
144 JAKOBS, Derecho, cit. nota n ${ }^{\circ}$ 143, pp. 1048 y 1049.

${ }^{145}$ MAÑALICH, "Norma e imputación”, cit. nota ${ }^{\circ}$ 141, p. 182.

${ }^{146}$ MATUS, "Los criterios", cit. nota ${ }^{\circ}$ 53, pp. 467.

${ }^{147}$ MATUS, "Los criterios", cit. nota n ${ }^{\circ}$ 53, pp. 486 y 487.

148 MAÑALICH, "El concurso", cit. nota n' 3, p. 1109.

${ }^{149}$ MAÑALICH, "Retribución”, cit. nota n 36, p. 64.
} 
La fundamentación de esto puede intentarse aduciendo el carácter accesorio de las formas subsidiarias de imputación respecto de las principales. Así, si la imputación extraordinaria tiene lugar en los casos que el autor "podría haber podido" cumplir con la norma, ${ }^{150}$ la misma sólo puede entenderse si se definen previamente las condiciones bajo las cuales se podía cumplir con ella, es decir, mediante una definición previa de la imputación ordinaria; igualmente, si la tentativa corresponde al intento de algo, ella no puede ser inteligible sino es en función de la consecución de ese algo; y en esa medida, es correcto afirmar que "la tentativa punible presupone la referencia a una realización típica consumada que se habría producido", 151 por lo que si esta última hubiera efectivamente tenido lugar, entonces la tentativa deja de ser punible. Ello es más claro aún al considerar que todo delito consumado se encontró previamente en estado de tentativa.

En el caso de la subsidiaridad por realización iterativa, la solución parece ser más fácil: la sucesión de tres golpes que causan tres lesiones leves soporta una descripción como "lesionar a otro"; es decir, si la totalidad del comportamiento sigue siendo abarcada en una única verificación de un tipo, entonces no hay más que una única infracción que amerita un único reproche restablecedor. En esos términos, es correcta la afirmación conforme a la cual un cambio en el sujeto pasivo ya impediría la apreciación de una única infracción, ${ }^{152}$ puesto que en ese caso, la totalidad del comportamiento realizado, es decir, los tres golpes a tres sujetos distintos, ya no pueden ser subsumidos como un único particular que constituye una única instanciación del universal "lesionar a otro": ya no será posible reconducir todas las realizaciones típicas a una única unidad típica de acción. ${ }^{153}$

Respecto de la realización de delitos de peligro seguida por la realización de delitos de daño, a menos que se pueda afirmar que entre los tipos en consideración hay una relación lógica conforme a la cual toda realización del tipo de daño supone la satisfacción de los presupuestos del tipo de peligro, no parecerá posible justificar el concurso aparente, sin perjuicio de la posibilidad, en caso de haber unidad de hecho, de apreciar un concurso ideal, lo que se verá más adelante. Igualmente, en los casos de hechos anteriores, coetáneos y posteriores co-penados, no habiendo formas subsidiarias de punición, no parece haber, desde la lógica retribucionista restablecedora, motivos para rechazar la punición. Y es que a diferencia de la retribución centrada en el daño producido, ahora la afirmación de una pura "relación empírica" entre los distintos ilícitos ${ }^{154}$ resulta insuficiente, puesto que es necesario afirmar una vinculación normativa entre ellos. Así, no hay entre la falsificación de un documento y su posterior uso para estafar, una relación en que la segunda alcance a constituir siquiera una "consecuencia" de la primera, ya que para ello ésta debería tener lugar sólo por necesidad causal a partir de la falsificación; ${ }^{155}$ en cambio, la estafa

\footnotetext{
${ }^{150}$ KINDHÄUSER, Urs, “IIndiferencia cómo dolo?”; en: KINDHÄUSER, Urs; GARCÍA, Percy; PASTOR, Nuria, Cuestiones actuales de derecho penal general y patrimonial, Lima: Universidad de Piura, 2005, p. 46.

${ }^{151}$ MAÑALICH, "Norma e imputación", cit. nota n 141, pp. 184 y 185.

152 SANZ MORÁN, "Concurso", cit. nota n 58, pp. 203 y ss., habla de la existencia de una nueva lesión.

${ }^{153}$ MAÑAICH, "El concurso", cit. nota ${ }^{\circ}$ 3, p. 1101.

${ }^{154}$ MATUS, "Los criterios", cit. nota n 53, p. 484.

${ }^{155}$ VON WRIGHT, Norma y acción, cit. nota $\mathrm{n}^{\circ}$ 6, p. 57.
} 


\section{Polít. crim. Vol. 8, № 16 (Diciembre 2013), Art. 5, pp. 500 - 543. \\ [http://www.politicacriminal.cl/Vol_08/n_16/Vol8N16A5.pdf]}

corresponde directamente al resultado de un segundo acto independiente del primero, y por ello, la norma de uno de los tipos no podría ser razón para omitir ambas acciones.

En contra de ello, en Jakobs se sostiene que en estos casos sigue tratándose de supuestos de especialidad, ${ }^{156}$ en que hay un único delito formulado varias veces con diversos grados de concreción, debiendo aplicarse sólo la formulación que lo abarca de manera completa; ${ }^{157}$ lo que equivaldría a mantener que en estos supuestos la expectativa defraudada continúa siendo la misma, sólo que ella formalmente se ha positivizado en diversas disposiciones jurídicas.

Si se partiera desde una prevención positiva referida al restablecimiento de la confianza general en la vigencia de la norma, ${ }^{158}$ entonces pareciera que toda ausencia de punición de una infracción normativa se podrá justificar en la medida que la sanción por una de las infracciones logre fortalecer en la población la confianza en las demás normas infringidas. Como ello hace referencia a un efecto fáctico que opera a nivel cognitivo, ${ }^{159}$ entonces se podría sostener en la medida que sea posible advertir una relación empírica entre las distintas realizaciones delictivas, esa vinculación podría justificar atribuir a una única punición múltiples efectos preventivo generales. Así, en caso de consunción de hechos menores que acompañan normalmente a un hecho delictivo principal, desde esta prevención general positiva podría sostenerse que por existir esa relación, a nivel cognitivo la población percibe que se está castigando a la totalidad de la actividad criminal realizada, con lo que se fortalecerían a nivel psicológico la vigencia de todas las normas involucradas.

\subsection{Delito continuado.}

Para una visión prevencionista, el análisis de los supuestos de consunción ha entregado ya la clave para una aproximación a los restantes supuestos de reiteración delictiva: en la medida que las acciones en sentido natural puedan ser todas reconducidas a un mismo factor subjetivo, esa reiteración podrá ser vista como indiciaria de un menores necesidades preventivo especiales o de una culpabilidad (anticuada) disminuida, lo que justificará un trato beneficioso respecto del que tendría lugar en caso de una aplicación mecánica de sanción por cada infracción.

Ello se ve con claridad al analizar el supuesto paradigmático de beneficio ante una multiplicidad de realizaciones delictivas: el delito continuado. Éste se encuentra en los márgenes de la unidad jurídica de acción, en los que una pluralidad de acciones en sentido natural se equiparan parcialmente con una unidad natural de acción, ${ }^{160}$ por lo que en principio, von Beling ${ }^{161}$ y Merkel $^{162}$ hacían referencia a él en los casos de realización

\footnotetext{
${ }^{156}$ JAKOBS, Derecho, cit. nota n 143, pp. 1059 a 1067.

${ }^{157}$ MATUS, Jean Pierre, "La teoría del concurso (aparente) de leyes en la dogmática alemana, desde sus orígenes hasta el presente (Segunda parte)", Ius et praxis, Vol. 7, n 2 (2001), p. 370.

${ }^{158}$ FEIJÓO, El injusto, cit. nota ${ }^{\circ} 116$, p. 80

${ }^{159}$ Véase: SILVA SÁNCHEZ, Jesús, "Del derecho abstracto al derecho real", InDret, 4 (2006), p. 5.

${ }^{160}$ MAÑALICH, "El concurso", cit. nota n ${ }^{\circ} 3$, p. 1032. Al respecto, véase también: CURY, Enrique, Derecho Penal. Parte General, Santiago: Ediciones Universidad Católica de Chile, 2005, pp. 653 y 654.

${ }^{161}$ VON BELING, Esquema, cit. nota n ${ }^{\circ}$ 58, p. 214.
} 
iterativa del tipo. En esa concepción del delito continuado era posible advertir una doble unidad subjetiva que luego se distinguiría: en la realización iterativa necesariamente nos encontraremos con unidad de dolo, pero igualmente, realizándose todas las acciones en una sucesión inmediata de tiempo, se deberá advertir una unidad de motivación ante la misma oportunidad. Es esta segunda cualidad la que se condice con el tratamiento privilegiado en función de una debilidad en el carácter del autor. Así, Mayer sostiene que esta figura requiere aprovechamiento de una misma oportunidad, por cuanto ello supone una misma resolución que, expresada en una pluralidad de acciones, justifica un tratamiento atenuado ya que el sujeto está cayendo siempre en la misma tentación. ${ }^{163}$ En cambio, la concurrencia de un dolo unitario haría "crecer la energía criminal", por lo que ya no se debería reconocer ningún beneficio. ${ }^{164}$ Igualmente, Mezger afirma que si desde un comienzo el dolo del autor ha abarcado la totalidad de las acciones delictuales, entonces corresponde la aplicación de la totalidad de las sanciones, ya que sólo se explica el tratamiento atenuado en caso que el sujeto sucumba siempre ante la misma oportunidad. ${ }^{165}$ Maurach hace referencia a la existencia de una misma resolución delictiva que sea expresión de una sumisión renovada y no de un dolo conjunto. ${ }^{166}$

Ello cambia con el finalismo, por lo que Welzel distingue dos formas de concebir el delito continuado, rechazando a la segunda de ellas, caracterizada como "unidad de conducción de vida", en la que se incluirá el aprovechamiento múltiple de una misma oportunidad y motivo; ${ }^{167}$ y prefiriendo la primera, en la que la existencia de un dolo unitario determinará la unidad de acción. ${ }^{168}$ En esa medida, el delito continuado más que corresponder a la consideración conjunta de varios delitos por la existencia de un elemento común, constituye un único injusto que no puede ser valorado una pluralidad de veces. Así, el trato más benigno se explicará de dos formas distintas: si se ve al delito continuado como expresión de una debilidad de carácter, entonces respecto de una pluralidad de delitos habrá una disminución de culpabilidad que justificará tratar de manera atenuada la multiplicidad de realizaciones típicas, las cuales mantendrán cada una, su contenido independiente de injusto. Pero si lo determínate es la unidad de dolo, entonces, con Welzel, se estará manteniendo la culpabilidad del autor, pero intentando una unificación de injustos.

El problema que esto presenta, es que ya en Welzel es posible un delito continuado respecto de tipos penales distintos, ${ }^{169}$ y si el dolo está referido a la representación de la realización del tipo objetivo, entonces en los casos de heterogeneidad de tipos penales, el dolo al que se hace referencia en la expresión "dolo unitario", no puede ser el dolo comprendido como elemento subjetivo del tipo. Pero, más aún, esta misma estructura del tipo debería impedir incluso la apreciación de un dolo unitario en caso de realización reiterada del mismo tipo

\footnotetext{
${ }^{162}$ MERKEL, Derecho, cit. nota n ${ }^{\circ}$, p. 380.

${ }^{163}$ MAYER, Derecho Penal, cit. nota n ${ }^{\circ}$ 58, pp. 197 y 198; 206 y 207.

${ }^{164}$ MAYER, Derecho Penal, cit. nota n ${ }^{\circ}$ 58, p. 213.

${ }^{165}$ MEZGER, Tratado. Tomo II, cit. nota n 58, p. 373; igualmente, SANZ MORÁN, "Concurso", cit. nota no 58, pp. 201 y ss.

${ }^{166}$ MAURACH/GÖSSEL/ZIPF, Parte General II, cit. nota n ${ }^{\circ}$ 58, p. 542.

${ }^{167}$ WELZEL, Derecho penal, cit. nota ${ }^{\circ} 14$, p. 219

${ }^{168}$ WELZEL, Derecho penal, cit. nota $n^{\circ} 14$, p. 218

${ }^{169}$ WELZEL, Derecho penal, cit. nota ${ }^{\circ} 14$, p. 220
} 
Polít. crim. Vol. 8, № 16 (Diciembre 2013), Art. 5, pp. 500 - 543.

[http://www.politicacriminal.cl/Vol_08/n_16/Vol8N16A5.pdf]

delictivo: si el dolo se encuentra referido al elemento objetivo del tipo, entonces no puede aceptarse que la representación conjunta del autor puede determinar la "unidad de la actividad típica", ${ }^{170}$ sino que por el contrario, a la multiplicidad de realizaciones a nivel objetivo deberá corresponder multiplicidad de dolos; es decir, no podría haber un dolo unitario respecto de una pluralidad a nivel objetivo, por lo que aquello que fuese "unitario" en esos supuestos no podría ser el dolo típico. Podría haber unidad en el "designio delictuoso", ${ }^{171}$ caracterizado por la unidad de pensamiento dirigido a un mismo fin; ${ }^{172}$ pero cada vez que la realización de ese designio satisfaga los presupuestos fácticos del tipo penal, nos encontraremos ante un acto individual doloso.

En el fondo, no pudiendo afirmarse una verdadera unidad de acción, resulta imposible afirmar un único dolo, y por el contrario, es inevitable apreciar una pluralidad de ellos, y es en ese punto en el cual cabe preguntarse porque un "todo querido unitariamente", ${ }^{173}$ constitutivo de una multiplicidad de dolos de contenido similar, ameritaría un tratamiento privilegiado. Y la respuesta debería reconducirse a las ventajas prácticas que la institución ofrece, ${ }^{174}$ o aceptar que el hito de la reiteración expresa una culpabilidad (anticuada) disminuida. ${ }^{175}$

De esta forma, la explicación preventivo-especial del tratamiento privilegiado del delito continuado debería tender a requerir como elemento negativo la ausencia de una planificación inicial que comprenda la realización de todos los ilícitos. Aunque aún si hubiera un "dolo unitario" podría igualmente defenderse la atenuación argumentando que todos los delitos obedecen a un único propósito; y que por ello el sujeto resulta menos peligroso que aquel que expresa multiplicidad de impulsos delictivos; pero lo que parecería difícil de sostener, en consideración a lo indicado con anterioridad, es una explicación de la atenuación justificada en la disminución del injusto.

Siendo ello así, una visión retributiva debería ser más favorable al tratamiento beneficioso otorgado al delito continuado, en la medida que se reconozca en la culpabilidad espacio para que la personalidad del delincuente sirva como atenuación. Y ello no puede descartarse en una visión como la de Hörnle, puesto que su crítica a la visión anticuada de la culpabilidad se explica en la medida que ella sirve para el aumento del la pena, en circunstancias que a su entender la culpabilidad sólo podría jugar disminuyéndola. ${ }^{176}$ Pero de seguirse una culpabilidad propia de la teoría del delito, sólo cabría considerar una

\footnotetext{
${ }^{170}$ WELZEL, Derecho penal, cit. nota ${ }^{\circ} 14$, p. 218

${ }^{171}$ ANTOLISEI, Manual, cit. nota ${ }^{\circ} 111$, p. 372

${ }^{172}$ MAGGIORE, Giuseppe, Derecho penal - El delito. La pena. Medidas de seguridad y sanciones civiles. Volumen II, Trad.: ORTEGA, José, Bogotá: Temis, 5a Ed., 1989, pp. 172 y 173.

${ }^{173}$ JESCHECK/WEIGEND, Tratado, cit. nota ${ }^{\circ} 23$, p. 772

${ }^{174}$ MIR, "Concurso de delitos", cit. nota $n^{\circ}$ 52, p. 103 Respecto de las dos posibilidades, MIR, Derecho Penal, cit. nota $\mathrm{n}^{\circ}$ 53, p. 654; STRATENWERTH, Derecho Penal, cit. nota $\mathrm{n}^{\circ} 25$, p. 451.

175 HAFFKE, Bernhard, "Reincidencia y medición de la pena", Trad.: SILVA SÁNCHEZ, Jesús: en: SCHÜNEMANN, Bernd, El sistema moderno de derecho penal. Cuestiones fundamentales, Madrid: Tecnos, 1991, p. 187

${ }^{176}$ HÖRNLE, Determinación, cit. nota $\mathrm{n}^{\circ} 41$, p. 68 , y en ello utiliza la metáfora del colador empleada por Horn.
} 
atenuante en caso de un defecto o debilidad de carácter que llegara a fundar una imputabilidad disminuida.

Ahora bien, a partir de una teoría retributiva expresiva es posible justificar límites máximos a las sanciones aplicables. Si el fundamento del reproche penal se encuentra en la falta de fidelidad al derecho, fidelidad que es legítimamente demandada en la medida que el autor forma parte de la comunidad que creó la norma; entonces, con Hegel, ${ }^{177}$ al penar se está reconociendo al delincuente como un miembro de la comunidad política, ${ }^{178}$ y ello importa reconocer límites al ejercicio punitivo, ya que el castigo impuesto sólo podrá constituir una pena si su ejecución no adopta una forma incompatible con el reconocimiento del autor. Por ello, un castigo que degrada a su destinatario no puede constituir una pena retributiva, ya que con ello se estaría negando la "base pragmática" ${ }^{179}$ del reproche; y ello sería predicable de una pena privativa de libertad tan larga que generara una "personalidad institucional". 180 Algo similar se podría señalar desde la retribución del daño, si es que -como Duff- se entiende que la pena no debe solo retribuir, ${ }^{181}$ sino que su ejecución debe perseguir finalidades preventivo especiales de resocialización, ${ }^{182}$ ya que en esa medida, una pena muy larga sería desaconsejable.

Por último, desde la prevención general fortalecedora de confianza o respeto de la norma, el beneficio al delito continuado se justificará en la medida que sea posible afirmar que dada la conexión entre los delitos, una única pena genera efectos psicológicos positivos suficientes respecto de la totalidad de vulneraciones. Es decir, si la pena debe producir un "equilibrio psíquico en la sociedad", satisfaciendo "necesidades coactivas de castigo", ${ }^{183}$ entonces se debería entender que tratándose de una única norma, o de normas de conducta similares, el desequilibrio social que produce la reiteración es menor que si las infracciones estuvieran desconectadas, y ello parecería implicar que el daño que causa el delito a la vigencia fáctica de la norma va disminuyendo en su intensidad a medida que se suceden las infracciones a la misma. Si ello fuera así, entonces la intensidad de la reacción penal requiere ser menos intensa que si se tratara de normas heterogéneas.

\subsection{Concurso real.}

Los otros casos de pluralidad de acciones en sentido natural de carácter delictivo corresponden al concurso real y a la reincidencia. Desde esta perspectiva, el tratamiento en principio neutro, del primero (de acumulación material) se explicaría justamente por cuanto el delito continuado constituye materialmente un concurso real ${ }^{184}$ en que los hechos

${ }^{177}$ HEGEL, G. W. F., Filosofía del Derecho. Trad.: MENDOZA DE MONTERO, Angélica, Buenos Aires: Claridad, $2^{\circ}$ ed., 2009, § 100: la pena reconoce al delincuente como ser racional; y al igual que en las teorías retributivas modernas, la pena no es más que una aplicación al delincuente de su propio derecho.

${ }^{178}$ MAÑALICH, "Pena y ciudadanía", cit. nota n ${ }^{\circ} 38, \mathrm{p} .75$.

${ }^{179}$ MAÑALICH, "La pena como retribución", cit. nota n 38, p. 193.

${ }^{180}$ MAÑALICH, "La pena como retribución”, cit. nota n ${ }^{\circ} 38$, pp. 177 y 178.

${ }^{181}$ DUFF, "Probation", cit. nota n ${ }^{\circ} 44$, p. 183.

${ }^{182}$ DUFF, "Restoration", cit. nota n ${ }^{\circ}$ 44, p. 48; DUFF, "Probation", cit. nota n ${ }^{\circ} 44$, p. 188.

${ }^{183}$ LUZÓN PEÑA, Diego Manuel, Estudios Penales, Barcelona: PPU S.A., 1991, pp. 273 y 274.

${ }^{184}$ MAGGIORE, La pena. Volumen II, cit. nota n ${ }^{\circ} 172$, p. 184. 
delictivos se encuentran relacionados, y en esa medida, la falta de relación entre las distintas acciones lleva, desde la perspectiva analizada, a una reiteración "estéril", que no pudiendo reconducirse a una misma debilidad de la personalidad, no fundamenta un trato más benigno. Por el contrario, como señalaba Maggiore, deberá procederse a la acumulación material, por cuanto el retardo en el descubrimiento del delito no debe afectar en nada. ${ }^{185}$ Así, se debería rechazar un tratamiento mediante exasperación, ${ }^{186}$ ya que con ello se estaría otorgando un beneficio injustificado. Al respecto, Merkel postulaba que sólo si las penas individuales eran bajas debía corresponder una acumulación material, pero que si el resultado de ella suponía una pena muy alta, las consideraciones de "política criminal" deben llevar a la aplicación de una agravación de la pena más intensa. ${ }^{187}$ La idea de fondo es expresada con claridad por Mayer: hay un reparo psicológico que la medida que "(P)ara el afectado es más soportable tener que cumplir dos veces dos años de presidio, repartidos en dos decenios de la vida, que cuatro años seguidos". Ello es negado por Manzini, para quien la única justificación reside en que una pena menor a la resultante del proceso de acumulación podría bastar ya para cumplir con su finalidad de crear motivos inhibitorios. ${ }^{188}$

Ahora bien, las consideraciones referidas a la excesiva severidad que podría significar la acumulación material, ya no dicen relación con el hito mismo de la reiteración delictiva en los supuestos de concurso real, sino que se explican por consideraciones referidas exclusivamente a efectos desaconsejables de la reiteración de penas, pero ellos se apreciarían en los mismos términos con independencia del concurso real. Así, el mismo Mayer sostiene que la reiteración por sí misma no debería tener efecto, indicando que lógicamente "la solución de la situación creada por el concurso real parece innecesaria". 189 Igualmente, desde la óptica retributiva, el tratamiento neutro del concurso real corresponde exactamente a la operación normal del derecho penal, por lo que se debería favorecer una acumulación material; a menos que la magnitud de la sanción así establecida resultara incompatible con el reconocimiento del delincuente como miembro de la comunidad política; o con la persecución de finalidades de resocialización.

\subsection{Reincidencia.}

Respecto de la reincidencia, en general se aducirá como su fundamento en tanto agravante a "la necesidad de una mayor represión penal por razones de prevención especial. Se sanciona con una pena más grave a quien, por la repetición de hechos delictivos de la misma clase, revela una inclinación a cometerlos", ${ }^{190}$ pero con ello se está suponiendo una valoración siempre negativa de la misma que no se condice con lo que hasta ahora visto. Si bien la reincidencia era indiciaria de la habitualidad, para von Liszt el agravamiento de la pena por reincidencia se explicaba en la medida que la reiteración tuviera lugar respecto de

\footnotetext{
${ }^{185}$ MAGGIORE, La pena. Volumen II, cit. nota $\mathrm{n}^{\circ} 172$, p. 187.

186 JESCHECK/WEIGEND, Tratado, cit. nota ${ }^{\circ} 23$, p. 786.

${ }^{187}$ MERKEL, Derecho, cit. nota ${ }^{\circ}$ 1, pp. 384 y 386; MEZGER, Tratado. Tomo II, cit. nota n 58, p. 392.

188 MANZINI, Vicenzo, Tratado de Derecho Penal. Tomo 3. Primera Parte. Teorías Generales, Trad.: SENTÍS, Santiago, 9a Ed., Buenos Aires, Ediar, 1949, p. 359.

${ }^{189}$ MAYER, Derecho Penal, cit. nota n 58, p. 639.

${ }^{190}$ LÓPEZ BARAJA, Jacobo, Tratado de Derecho Penal. Parte General, Navarra: Aranzadí, 2010, p. 859.
} 
los tipos de delitos que se cometían habitualmente, ya que en esos casos la reiteración probablemente respondía a habitualidad, ${ }^{191}$ y por lo mismo, no correspondía una agravación generalizada. Igualmente, Welzel hacía presente que la actividad delictuosa repetida, como agravante, presupone a un autor peligroso, y que para afirmar esa calidad no basta con la realización de varios hechos. ${ }^{192}$

Así las cosas, la reincidencia como agravante se explica cambiando de perspectiva: ahora ya no se ve el hito de la reiteración como un indicio de debilidad a ser tratado con benevolencia, sino que como manifestación de una "extraordinaria resistencia" a los motivos de inhibición que ofrece el derecho penal, aumentando con ello la "imputabilidad psíquica". ${ }^{193}$ En contra de lo anteriormente visto, acá la reiteración no es el síntoma de una personalidad defectuosa, sino que por el contrario, el defecto de carácter consiste justamente la realización reiterada de acciones en sentido natural delictivas. Estas cualidades personales se denominan "capacidad delictiva" y se corresponde con la criminalidad potencial del delincuente, la cual se determina principalmente por la existencia de condenas pasadas ${ }^{194}$ que demuestran una persistente voluntad de delinquir. ${ }^{195}$

Ahora bien, al igual que en la visión de la reiteración como debilidad, en esta corriente, de la cual Manzini constituye un exponente paradigmático, también existe una superposición entre los ámbitos determinantes de la culpabilidad y de las necesidades preventivas, por cuanto la mayor imputabilidad psíquica hace del reenciéndete un sujeto cuyo delito causa mayor daño, ya que no sólo afecta el interés específico tutelado, sino que también el interés genérico en el mantenimiento del orden jurídico, ${ }^{196}$ por lo que el Estado ahora tiene un doble deber de protección. Maggiore parte de una base similar: la condena anterior agrava la imputabilidad, ya que se demuestra una voluntad antijurídica dominante y mayor peligrosidad, mereciendo una medida preventiva y represiva más poderosa, ya que se tratará de un autor con "mayor perversión", por lo que la cantidad de pena, para él, es insuficiente. $^{197}$

Ahora bien, si la comisión de reiterados delitos constituye de por sí una mayor peligrosidad, ya sea entendida ésta como un indicador de necesidades preventivas, o relacionada con la visión anticuada de la culpabilidad, en cualquier caso resultará que para la operación de la reincidencia no es necesario el haber cumplido la pena; ${ }^{198}$ por el contrario, si la reiteración incide por sí sola en la mayor "imputabilidad", entonces bastará la pura condena anterior, y más aún, como bien señala Manzini, ese aumento de "inclinación delictuosa” podría ser observado ya en los supuestos de concurso real. ${ }^{199}$

\footnotetext{
${ }^{191}$ VON LISZT, La idea, cit. nota ${ }^{\circ} 17$, pp. 121 y 122.

${ }^{192}$ WELZEL, Derecho penal, cit. nota ${ }^{\circ} 14$, p. 253.

${ }^{193}$ MANZINI, Tratado. Tomo 3, cit. nota $\mathrm{n}^{\circ} 189$, p. 462.

${ }^{194}$ ANTOLISEI, Manual, cit. nota n ${ }^{\circ} 111$, pp. 458 y 462.

195 ANTOLISEI, Manual, cit. nota $\mathrm{n}^{\circ} 111$, p. 472.

${ }^{196}$ MANZINI, Tratado. Tomo 3, cit. nota n ${ }^{\circ} 189$, pp. 462 y 463.

${ }^{197}$ MAGGIORE, La pena. Volumen II, cit. nota ${ }^{\circ} 172$, p. 199.

${ }^{198}$ MANZINI, Tratado. Tomo 3, cit. nota n ${ }^{\circ} 189$, pp. 462 y 463.

${ }^{199}$ MANZINI, Tratado. Tomo 3, cit. nota ${ }^{\circ} 189$, p. 360.
} 


\section{Polít. crim. Vol. 8, N 16 (Diciembre 2013), Art. 5, pp. 500 - 543. [http://www.politicacriminal.cl/Vol_08/n_16/Vol8N16A5.pdf]}

En contra de ello se puede oponer una corriente como la iniciada por Carrara, en la que se justificaba la reincidencia como agravante recurriendo a una argumentación preventivo especial conforme a la cual, si se presume que la pena asignada al delito es la adecuada a la necesidad de reprimirlo, entonces una vez que se delinque, la pena aplicada debería retraer al delincuente de una nuevo infracción. Respecto de los reincidentes ello no ocurría, por lo que había certeza de que la pena original no sirvió para retraerlo, dejando en evidencia un defecto especial del sujeto: si el individuo delinquió por segunda vez, no puede esperarse que la pena conminada le sirva de freno suficiente, y puesto que se muestra insensible a la pena ordinaria, debe aplicársele una más fuerte. ${ }^{200}$ Ahora bien, como Carrara no entiende la pena como una medida de corrección individual, debe reconducir sus razones preventivoespeciales a su concepto de pena destinada al restablecimiento de equilibrio social, y para ello afirma que la finalidad de tranquilizar a los hombres buenos que se han conmovido por el delito, no se logra actuando ante un individuo excepcional con mecanismos normales, sino que el equilibrio requiere ahora una pena especial. ${ }^{201}$

En este caso, y a diferencia de lo propuesto por Manzini, en una teoría como la de Carrara la reincidencia se fundamenta en que la pena anterior se ha mostrado como insuficiente, por lo que para su operación la condena debe necesariamente haberse cumplido, ${ }_{203}^{202}$ y por ello afirma que solo recae verdaderamente en quien ha expiado su primera condena. ${ }^{203}$

El problema con esta lógica lo alcanza a advertir el mismo Carrara: por las mismas razones indicadas, es en principio correcta una mayor agravación si aumenta la reincidencia, ${ }^{204}$ y con ello no sólo se podría llegar a penas exageradamente altas, sino que queda de manifiesto que el aumento cuantitativo de pena no asegura una mejor respuesta al caso concreto. Ello es puesto de manifiesto por Jescheck, quien afirma que del hecho de que las condenas previas hagan patente que las sanciones impuestas no han servido para modificar el comportamiento, de ello no se puede asumir que mayores sanciones ahora sí serán beneficiosas. $^{205}$ Igualmente, Maurach sostenía que caso de reincidentes, la respuesta preventivo especial debe consistir en una modificación de la aproximación al sujeto, pudiendo modificarse la sanción desde una pena pecuniaria que en ya se mostró ineficaz, a una de presidio. ${ }^{206}$

Ahora bien, vale la pena hacer presente que, muy al contrario de lo que sostenía Antolisei, conforme al cual la reincidencia como agravante no podía explicarse por efectos de alarma social, ya que sólo el juez sabía que quien había cometido el nuevo delito tenía condenas anteriores, ${ }^{207}$ han sido justamente consideraciones de carácter preventivo general las que se encuentran en la raíz de la versión extrema de agravación por reincidencia, el three

200 CARRARA, Francesco, Opúsculos de derecho criminal. Volumen II, Trad.: ORTEGA, José; GUERRERO, Jorge, Santa fe de Bogotá: Temis, 2000, p. 98.

${ }^{201}$ CARRARA, Opúsculos. Volumen II, cit. nota n ${ }^{\circ} 200$, p. 99.

${ }^{202}$ MAGGIORE, La pena. Volumen II, cit. nota n ${ }^{\circ} 172$, p. 202.

${ }^{203}$ CARRARA, Opúsculos. Volumen II, cit. nota n ${ }^{\circ} 200$, p. 102.

${ }^{204}$ CARRARA, Opúsculos. Volumen II, cit. nota n ${ }^{\circ} 200$, p. 112.

${ }^{205}$ JESCHECK/WEIGEND, Tratado, cit. nota ${ }^{\circ} 23$, p. 962.

${ }^{206}$ MAURACH/GÖSSEL/ZIPF, Parte General II, cit. nota n ${ }^{\circ}$ 58, p. 767.

${ }^{207}$ ANTOLISEI, Manual, cit. nota n ${ }^{\circ} 111$, p. 472. 
strikes. ${ }^{208}$ Llevando esto a los términos de la prevención general positiva, si ella busca impedir que la norma de conducta desaparezca en la práctica por falta de seguimiento, ${ }^{209}$ entonces es posible entender que la acción del reincidente afecta de manera más grave la confianza en su vigencia fáctica, ya que la reiteración delictiva posterior a la condena mostraría que las reacciones normales ante el no seguimiento no han derivado en un mayor respeto a ella: ${ }^{210}$ si la pena debe contrarrestar la perturbación a futuras organizaciones de los ciudadanos, ${ }^{211}$ entonces la reincidencia evidencia que a pesar del castigo, las organizaciones igualmente fueron afectadas nuevamente.

Desde las teorías retributivas que hemos visto, la existencia de condenas anteriores no debería jugar efecto alguno, ya que constituirían justamente el tipo de antecedente que, ni desde la perspectiva de la víctima aumenta el daño del delito, ni desde la óptica restabilizadora puede verse como factor que genera un mayor daño a la vigencia de la norma.

\subsection{Concurso ideal.}

Éste es comprendido de manera generalizada como la realización de más de un tipo delictivo mediante una única acción. ${ }^{212}$ Pero -como se adelantó al inicio de este trabajo- si la unidad de acción se determina en función de la realización de los elementos del tipo, como ocurre en razón de la unidad típica de acción, entonces en el concurso ideal habrá al menos dos acciones, y ello determinará que la afirmación conforme a la cual el concurso ideal supone que "se ha infringido, mediante una misma acción, varias leyes penales, o la misma ley penal varias veces", constituya una imposibilidad lógica, ${ }^{213}$ ya que la pluralidad de infracciones importará, para la unidad típica de acción, que se recorten una multiplicidad de "fragmentos de actividad humana", ${ }^{214}$ cada uno de los cuales será visto como una unidad.

Ello determina que la unidad de acción que requiere el concurso ideal no podrá definirse por la realización del tipo. La solución del problema pasa por volver a la explicación de los casos de concurso aparente por especialidad. En ellos, la no punición por la infracción de uno de los tipos realizados descansaba en que el seguimiento de una sola norma servía para

\footnotetext{
${ }^{208}$ ZYSMAN, Diego, Castigo y determinación de la pena en los Estados Unidos. Un estudio sobre las United States Sentencing Guidelines. Madrid: Marcial Pons, 2013, p. 112.

209 AMELUNG, Knut, "El concepto de <bien jurídico> en la teoría de la protección penal de bienes jurídicos", en: HEFENDEHL, Roland, La teoría del bien jurídico: ¿fundamento de legitimación del derecho penal o juego de abalorios dogmáticos?, Trad: ORTIZ DE URBINA, Ínigo; Madrid: Marcial Pons, 2007, p. 259.

${ }^{210}$ FEIJOO, El injusto, cit. nota ${ }^{\circ} 116$, p. 80

${ }^{211}$ FEIJOO, Retribución, cit. nota n ${ }^{\circ} 36$, p. 488.

${ }^{212}$ STRATENWERTH, Derecho Penal, cit. nota $\mathrm{n}^{\circ}$ 25, p. 460; FRISTER, Derecho penal, cit. nota $\mathrm{n}^{\circ} 28$, $\mathrm{p}$. 664; MIR, Derecho Penal, cit. nota ${ }^{\circ}$ 53, p. 656; JAKOBS, Derecho, cit. nota $n^{\circ} 143$, p. 1100; WELZEL, Derecho penal, cit. nota ${ }^{\circ}$ 14, p. 225; MAURACH/GÖSSEL/ZIPF, Parte General II, cit. nota ${ }^{\circ}$ 58, p. 550; MEZGER, Tratado. Tomo II, cit. nota ${ }^{\circ} 58$, p. 389.

${ }^{213}$ FRISTER, Derecho penal, cit. nota n ${ }^{\circ} 28$, p. 667.

${ }^{214}$ MIR, Derecho Penal, cit. nota n ${ }^{\circ} 53$, p. 650.
} 


\section{Polít. crim. Vol. 8, № 16 (Diciembre 2013), Art. 5, pp. 500 - 543. \\ [http://www.politicacriminal.cl/Vol_08/n_16/Vol8N16A5.pdf]}

evitar las dos infracciones, por lo que era imposible reconocer a ambas normas simultáneamente como razones excluyentes. Ello significa que respecto de las acciones que satisfacen ambos tipos involucrados, ya en abstracto existe una evitabilidad conjunta entre ellas, determinada por cuanto una misma omisión supone la no realización de ninguna de las acciones delictivas. ${ }^{215}$

En el caso del concurso ideal, también será posible unificar las dos unidades jurídicas de acción mediante la aplicación del test indicado; pero esta vez, ello únicamente se podrá afirmar considerando la configuración concreta del comportamiento realizado: es perfectamente posible un homicidio sin aborto y viceversa, por lo que el seguimiento de una de esas normas no implica necesariamente nada respecto del seguimiento de la otra; pero contingentemente sí puede establecerse una relación, ya que si de un disparo se mata y se aborta, habrá dos acciones jurídicas, pero ellas constituirán un único hecho delictual, unidad que se afirmará no en consideración a las descripciones típicas, sino que "a través de ellas", ${ }^{216}$ en razón de la evitabilidad conjunta de ambas. Así, en el caso concreto, el seguimiento de una de las normas involucradas significaba omitir el comportamiento que constituía ambas acciones, y con ello, se puede fundamentar una atenuación de la pena.

Ello es más claro aún cuando la realización de los tipos delictivos no ocurre en un mismo instante, sino que se suceden temporalmente. Así, si un único comportamiento realiza dos tipos penales de forma tal que es posible afirmar que ha sido la realización de uno de esos tipos lo que ha producido la realización del otro. Ese podría ser el caso -por ejemplo- de los supuestos de hechos anteriores co-penados, en que el abandono de un niño produce su posterior muerte. En ese supuesto nos encontraremos con dos realizaciones típicas que pueden ser unificadas en atención a la posibilidad de evitación conjunta. ${ }^{217}$ Mientras que en un examen abstracto el seguimiento de una de las normas no dice nada respecto del seguimiento de la otra; ante el caso concreto que podemos ver esa relación.

En los términos de von Wright, se afirmaría que hay un único acto, que es el de abandonar a un niño, el cual está definido lógicamente por transformar un mundo en que el niño no está abandonado, en uno en que sí lo está, transformación que constituye el resultado mismo del acto. La relación entre el acto y el resultado es intrínseca, porque sin ese resultado, la acción ya no es "abandonar un niño"; y en ese esquema, la posterior muerte ya no se relaciona lógicamente con ese acto, sino que es una relación extrínseca, y sólo correspondería a su "consecuencia" si se puede afirmar que ha tenido lugar por "necesidad causal o natural". ${ }^{218}$ Pero en la medida que esa consecuencia no depende de la realización de un nuevo "acto", la norma de homicidio sí le afectaría. Si ella constituye una razón para omitir un comportamiento que produce la muerte, y en el caso concreto el abandono tiene como consecuencia la muerte, entonces será correcto afirmar que la norma que prohíbe el

\footnotetext{
${ }^{215}$ MAÑALICH, Juan Pablo, "El principio ne bis in idem en el derecho penal chileno", Revista Estudios de la Justicia $\mathrm{n}^{\circ} 15$ (2011), p. 153.

${ }^{216}$ MAÑALICH, "El principio ne bis in idem", cit. nota $\mathrm{n}^{\circ} 215$, p. 152, afirmando un concepto hecho "débilmente extensional", en oposición al intencional, el cual se corresponde con la unidad típica de acción.

${ }^{217}$ MAÑALICH, "El principio ne bis in idem", cit. nota ${ }^{\circ} 215$, p. 153.

${ }^{218}$ VON WRIGHT, Norma y acción, cit. nota n ${ }^{\circ} 6$, pp. 56 y ss.
} 
homicidio constituye una razón para omitir el abandono; y siendo ello así, producir el abandono significará desconocer a la norma que prohíbe el homicidio como una razón para la omisión.

Al igual que en el caso de concurso aparente por especialidad, pero ahora sólo ante los hechos concretos, habrá sido imposible reconocer simultáneamente como razones excluyentes a ambas normas, por lo que la sanción por la infracción de una de las normas expresará la totalidad de reproche por falta de fidelidad. Siendo ello así, el fundamento de un tratamiento al concurso ideal más severo que respecto del concurso aparente, pero menos riguroso que en el concurso real, ${ }^{219}$ se explica ya por razones prácticas: si de un disparo a una embarazada se le da muerte a ella, y esa muerte produce posteriormente el aborto, será posible advertir que la norma que prohíbe el aborto ha sido una razón para omitir la muerte; y por lo tanto, si se aceptara el concurso aparente, sólo se castigaría por el delito de aborto. Pero la razón normativa de fondo se encuentra en que al ser la relación entre los tipos sólo contingente, entonces resulta posible, en abstracto, reconocer a ambas normas simultáneamente como razones excluyentes, y de allí se podría afirmar que le corresponde al destinatario el deber de asegurarse de no ponerse a sí mismo en situación de no poder reconocer a una de las normas. Ello daría pie para sostener que si el destinatario ha incumplido ese deber, entonces su conducta sí ha afectado la validez de cada una de las normas, aún cuando no se le pueda reprochar íntegramente el no seguimiento de ambas, ya que habría bastado el reconocimiento de sólo una para evitar ambas acciones jurídicamente identificadas.

Ahora bien, desde la perspectiva de una teoría retributiva centrada en la víctima, la superposición normativa carece de relevancia, y en la medida que los dos hechos delictivos generen, cada uno, un daño relevante e independiente, no habría razón para reconocer una atenuación fundada en la forma de comportamiento. La idea conforme a la cual el que el sujeto se haya puesto en contra del derecho en un solo momento, indicaría una menor persistencia en su comportamiento antisocial, ${ }^{220}$ si bien será relevante a efectos de juzgar su peligrosidad (puesto que por regla general quien ha realizado una única acción delictiva en sentido natural expresaría menores necesidades preventivas que quien realiza varias), fundamentando así una explicación preventiva del tratamiento atenuado del concurso ideal respecto del real, no incidiría en la apreciación del daño; por lo que desde una teoría de la retribución como la defendida por von Hirsch no se justificaría un trato diferenciado entre ambas formas de concurso, debiéndose en los dos casos procederse a una acumulación material que dé cuenta de todo el perjuicio que, de manera estandarizada, una víctima ideal habría objetivamente experimentado. ${ }^{21}$

\footnotetext{
${ }^{219}$ Lo que para Cuerda Riezu constituiría una exigencia del principio non bis in idem (CUERDA RIEZU, Antonio, "El concurso de delitos en el Borrador de Anteproyecto de Código Penal de 1990", ADPCP, Tomo $44, \mathrm{n}^{\circ} 3$ (1991), p. 850).

${ }^{220}$ ANTOLISEI, Manual, cit. nota n ${ }^{\circ} 111$, p. 369.

${ }^{221}$ Con esta estandarización se busca dar paso a mayores niveles de pluralismo, evitando evaluaciones que descansen en las metas particulares del sujeto; en: VON HIRSCH, Andrew; JAREBORG, Nils, "Gauging criminal harm: A living-standard analysis", Oxford Journal of Legal Studies, Vol. 11 (1991), p. 10. Ahora bien, Von Hirsch afirma que en los casos en que la víctima es una "clase" entera, en lugar de un individuo, sólo regirá el proceso indicado si se afecta a todos de forma considerable; pero si resulta que a cada individuo
} 


\section{Polít. crim. Vol. 8, № 16 (Diciembre 2013), Art. 5, pp. 500 - 543. [http://www.politicacriminal.cl/Vol_08/n_16/Vol8N16A5.pdf]}

Por otro lado, desde la prevención general referida al respeto a la norma, se sostiene que sólo se reestabilizan las normas si las penas son percibidas como "idóneas para mejorar la convivencia". ${ }^{222}$ Con ello, es posible advertir una argumentación escalonada respecto de los efectos psicológicos relevantes: es la percepción por parte de la ciudadanía de que la pena es justa, lo que produce un subsecuente estado psicológico referido al fortalecimiento de la confianza en la vigencia de la norma, que a su vez permite orientarse sin tener que contar en cada momento con cualquier comportamiento imprevisible. ${ }^{223}$ Ahora bien, es en la producción de ese primer estado mental donde se abre la puerta a una atenuación en consideración a la unidad de acción.

Y es que, como argumenta Luzón Peña, con esta forma de prevención especial el legislador debe tener especialmente en cuenta las valoraciones sociales sobre gravedad del delito e intensidad de la reacción penal, pero ello no solo abre la puerta para aumentos de sanción en consideración al uso con sentido autoritario de la seguridad ciudadana, ${ }^{24}$ sino que también podría servir para disminuir la sanción penal en base a consideraciones alejadas de los presupuestos retributivos analizados. Así, el que la generalidad perciba un castigo como adecuado a una falta no tiene porque ser coincidente con la apreciación del reproche merecido en consideración al daño causado o la falta de fidelidad al derecho. Así, al haber evitabilidad conjunta, se puede afirmar la existencia de una única voluntad delictiva, lo cual, aunque no influya especialmente en el daño causado ni en la culpabilidad del autor; si podría ser percibido por la ciudadanía como merecedor de un menor reproche. En esa medida, esta forma de prevención general podría constituir una forma de retribución conforme al sentimiento social de justicia, el cual no se encontraría atado a las construcciones dogmáticas de las actuales teorías retributivas, y que tampoco tendría que coincidir con la atribución de peligrosidad que puede tener lugar desde la prevención especial. $^{225}$

\footnotetext{
se le causa un daño menor, entonces corresponde modificar la teoría del estándar de vida para poder agregar los daños pequeños individuales. Problema aparte es aquel en que el daño sólo se produce por efecto de la acumulación. En este supuesto, la clave es atribuir el daño a los agentes, debiendo preguntar por aquellas circunstancias bajo las cuales es correcto hacer a una persona responsable por efectos que tienen lugar sólo en caso de concurrir otros actores independientes. Al respecto, Von Hirsch reconoce que puede ser necesario recurrir a otros criterios para determinar la gravedad de los delitos, ya que la teoría del estándar de vida tiene como objetivo los casos de daño en víctimas individuales (pp. 33 y 34). Respecto del daño causado por los delitos de cuello blanco, Von Hirsch afirma que si se consideran las consecuencias y riesgos generados por las conductas delictivas, la importancia de los intereses afectados y otros factores, se entenderá que sólo algunos de estos delitos serían tan graves como los delitos violentos o de amenazas; en: VON HIRSCH, Andrew, "Desert and white collar criminality: A response to Dr. Braithwaite", The Journal of criminal Law \& Criminology, Vol. 73, $\mathrm{n}^{\circ} 3$ (1982), p. 1169.

${ }^{222}$ HASSEMER, Winfried, Fundamentos del derecho penal, Trad: MUÑOZ CONDE, Francisco; ARROYO ZAPATERO, Luis, Barcelona: Bosch, 1984, p. 393.

${ }^{223}$ JAKOBS, Derecho, cit. nota ${ }^{\circ} 143$, p. 9.

${ }^{224}$ LUZÓN PEÑA, Estudios Penales, cit. nota n 183, pp. 269 a 270.

${ }^{225}$ En términos críticos: LUZÓN PEÑA, Estudios Penales, cit. nota n ${ }^{\circ} 183$, pp. 274 y 275.
} 
SZCZARANSKI, Federico. “Aproximación a la reiteración delictiva y a la teoría concursal desde la teoría de la pena”

\section{Conclusiones}

1.- Es posible afirmar una relación entre el tratamiento de los diversos supuestos de reiteración delictiva y las distintas teorías de la pena; no obstante lo cual, esta relación es más débil de lo que se podría haber pensado en un principio.

2.- En términos generales, desde la prevención especial, el tratamiento privilegiado de algunos supuestos de reiteración parece poder justificarse aduciendo que, en la medida que las distintas actividades delictivas se encuentren relacionadas, ello indicaría una menor peligrosidad del delincuente de la que se podría afirmar si se tratara de infracciones independientes. Esas mismas consideraciones pueden servir de base para afirmar una menor culpabilidad, entendida en términos anticuados. Esta relación entre las diversas realizaciones delictivas puede ser afirmada en los casos de delito continuado, concurso ideal, concurso aparente por subsidiaridad y por consunción.

3.- Desde una lógica retributiva, en que la pena restablece la vigencia de la norma infringida, el tratamiento atenuado deberá justificarse en la existencia de una cualidad normativamente relevante en el caso de reiteración. Así, tanto en los supuestos de concurso aparente por especialidad, como en el concurso ideal, la atenuación se podría explicar aduciendo la imposibilidad -ya en abstracto en el primer supuesto, y sólo en el caso concreto en el segundo- de seguir simultáneamente las normas infringidas. Los casos de concurso aparente por subsidiaridad se deberán explicar en función de la relación justamente- de subsidiaridad de una forma de imputación respecto de la otra. En la reincidencia, el concurso real y el delito continuado no parecen advertirse relaciones normativas que pudieran desde esta óptica justificar un trato menos severo que el propio de la operación por defecto de la norma secundaria en caso de infringirse la norma de conducta; por lo que la atenuación sólo podría explicarse aduciendo que una aplicación regular de todas las sanciones resulta incompatible con el reconocimiento del condenado como un miembro de la comunidad política.

4.- Si la retribución se encuentra referida al daño ocasionado, entonces no se vislumbran razones para el trato privilegiado del delito continuado ni del concurso ideal, y tampoco se puede explicar la agravación en función de reincidencia. En cambio, se encuentra justificada la absorción en los concursos aparentes por especialidad, y en los casos en que el delito secundario no genere un daño independiente.

5.- Finalmente, si se sigue una corriente preventivo general referida a la producción de un efecto empírico a nivel psicológico en la población, resulta más difícil postular un tratamiento particular a los diversos supuestos de reiteración, por cuanto la solución correcta dependerá de la comprobación empírica de la producción de un fortalecimiento de la confianza en la norma infringida. Así las cosas, la compatibilización del tratamiento privilegiado de los supuestos de delito continuado con esta lógica preventivo especial positiva, requeriría afirmar que la intensidad de la afectación cognitiva que produce una infracción, va decreciendo marginalmente con la sucesión de infracciones. 
Polít. crim. Vol. 8, № 16 (Diciembre 2013), Art. 5, pp. 500 - 543.

[http://www.politicacriminal.cl/Vol_08/n_16/Vol8N16A5.pdf]

\section{BIBLIOGRAFÍA}

1. AMELUNG, Knut, "El concepto de <bien jurídico $>$ en la teoría de la protección penal de bienes jurídicos", en: HEFENDEHL, Roland, La teoría del bien jurídico: ¿fundamento de legitimación del derecho penal o juego de abalorios dogmáticos?, Trad: ORTIZ DE URBINA, Íñigo; Madrid: Marcial Pons, 2007.

2. ANTOLISEI, Francesco, Manual de derecho penal. Parte general, Trad.: GUERRERO, Jorge; AYERRA, Marino, Bogotá, Temis, 8 Ed., 1988.

3. BECCARIA, Cesare, De los delitos y de las penas, Trad.: DE LAS CASAS, Juan, Madrid: Alianza editorial, 2002.

4. BERISTAIN, Antonio, "Estructura e ideología de la nueva defensa social", ADPCP, Tomo 14, n 3 (1961).

5. BOBBIO, Norberto, Teoría general del Derecho, Trad.: ROZO ACUÑA, Eduardo, Bogotá: Temis, 1992.

6. CANCIO MELIÁ, Manuel; FEIJOO SÁNCHEZ, Bernardo, “¿Prevenir riesgos o confirmar normas? La teoría funcional de la pena de Günther Jakobs"; en: JAKOBS, Günther, La pena estatal: significado y finalidad, Trad: CANCIO MELIÁ, Manuel; FEIJOO SÁNCHEZ, Bernardo; Navarra: Civitas, 2006.

7. CARRARA, Francesco, Opúsculos de derecho criminal. Volumen I, Trad.: ORTEGA, José; GUERRERO, Jorge, Santa fe de Bogotá: Temis, 2000.

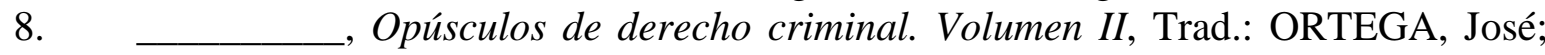
GUERRERO, Jorge, Santa fe de Bogotá: Temis, 2000.

9. CEREZO MIR, José, "El delito como acción culpable", ADPCP, Tomo 49, Fasc. 1 (1996).

10. CUERDA RIEZU, Antonio, "El concurso de delitos en el Borrador de Anteproyecto de Código Penal de 1990”, ADPCP, Tomo 44, n 3 (1991).

11. _ "La unidad de delitos en la jurisprudencia del Tribunal Supremo"; en: SILVA SÁNCHEZ, Jesús (Ed.), Política criminal y nuevo derecho penal. Libro homenaje a Claus Roxin, Barcelona: Bosch Editor, 1997.

12. CURY, Enrique, Derecho Penal. Parte General, Santiago: Ediciones Universidad Católica de Chile, 2005.

13. DEMETRIO CRESPO, Eduardo, "Notas sobre la dogmática de la individualización judicial de la pena", Revista Jurídica de Castilla la Mancha, $\mathrm{n}^{\circ} 35$ (2003).

14. _ _ Eduardo, Prevención general e individualización judicial de la pena. Salamanca: Ediciones Universidad de Salamanca, 1999.

15. DUFF, Anthony, "Restoration and retribution"; en: VON HIRSCH, Andrew; ROBERTS, Julian; BOTTOMS, Anthony (Eds.), Restorative Justice and Criminal Justice Competing or Reconcilable Paradigms?, Oxford, Portland and Oregon: Hart Publishing, 2003.

16. DUFF, R. A., "Harms and wrongs". Buffalo Criminal Law Review n ${ }^{\circ} 13$ (20012002).

17. — _Probation, punishment and restorative justice: Should all tourism be engaged in Punishment?", The Howard Journal, Vol. 42, n 2 (2003).

18. FEIJOO SÁNCHEZ, Bernardo, El injusto penal y su prevención ante el nuevo código penal de 1995, Madrid: Editorial Colex, 1997. 
SZCZARANSKI, Federico. “Aproximación a la reiteración delictiva y a la teoría concursal desde la teoría de la pena”

19. , Retribución y prevención general. Un estudio sobre la teoría de la pena y las funciones del derecho penal, Montevideo-Buenos Aires: IB de f, 2007.

20. FEINBERG, Joel, "The expressive function of punishment"; en: FEINBERG, Joel, Doing \& deserving. Essays in the theory of responsibility, Princeton, New Jersey: Princeton University Press, 1974.

21. FEUERBACH, Anselm, Tratado de derecho penal común vigente en Alemania, Trad.: ZAFFARONI, Raúl; HAGEMEIER, Irma, Buenos Aires: Hammurabi, 1989.

22. FRISTER, Helmut, Derecho penal. Parte General, Trad.: SANCINETTI, Marcelo, Buenos Aires: Hammurabi, 2009.

23. HAFFKE, Bernhard, "Reincidencia y medición de la pena", Trad.: SILVA SÁNCHEZ, Jesús: en: SCHÜNEMANN, Bernd, El sistema moderno de derecho penal. Cuestiones fundamentales, Madrid: Tecnos, 1991.

24. HASSEMER, Winfried, "Fines de la pena en derecho penal"; en: MIR, Santiago (Ed.), Derecho penal y ciencias sociales, Barcelona: Universidad Autónoma de Barcelona, 1982.

25. _ Fundamentos del derecho penal, Trad: MUÑOZ CONDE, Francisco; ARROYO ZAPATERO, Luis, Barcelona: Bosch, 1984.

26. HEGEL, G. W. F., Filosofía del Derecho. Trad.: MENDOZA DE MONTERO, Angélica, Buenos Aires: Claridad, $2^{\circ}$ ed., 2009.

27. HÖRNLE, Tatjiana, "Distribution of punishment: The role of a victim's perspective"; en: Buffalo Criminal Law Review, Vol. 3 (1999).

28. —— "La concepción anticuada de la culpabilidad en la jurisprudencia y doctrina tradicionales de la medición de la pena", Trad.: MARTÍN LORENZO, María, ADPCP, Vol. LIV (2001).

29. —La protección de sentimientos en el StGB", Trad.: MARTíN LORENZO, María, en: HEFENDEHL, Roland, La teoría del bien jurídico: ¿fundamento de legitimación del derecho penal o juego de abalorios dogmáticos?, Madrid: Marcial Pons, 2007.

30. —_ "Offensive behavior and German penal law", Buffalo Criminal Law Review, Vol. 5 (2001).

31. _ Determinación de la pena y culpabilidad. Notas sobre la teoría de la determinación de la pena en Alemania, Trad.: FRANCHINI, María Belén, Buenos Aires: Fabián J. Di Plácido, 2003.

32. HRUSCHKA, Joachim, "La imputación ordinaria y extraordinaria en Pufendorf. Sobre la historia y el significado de la diferencia entre actio libera in se y actio libera in sua causa", Revista de derecho penal y criminología, $2^{\mathrm{a}}$ Época, $\mathrm{n}^{\circ} 12$ (2003).

33. , "Reglas de comportamiento y reglas de imputación”, ADPCP, tomo XLVII, Fasc. III (1994).

34. _ _ _Sobre la utilidad del hexágono deontológico para el derecho", Trad.: SÁNCHEZ-OSTIZ, Pablo; en: HRUSCHKA, Joachim, Imputación y derecho penal. Estudios sobre la teoría de la imputación. Navarra: Aranzadi S.A., 2005. 
Polít. crim. Vol. 8, № 16 (Diciembre 2013), Art. 5, pp. 500 - 543.

[http://www.politicacriminal.cl/Vol_08/n_16/Vol8N16A5.pdf]

35. JAKOBS, Günther, "El sistema de imputación jurídicopenal. Conocimiento y desconocimiento de la norma", Trad.: SÁNCHEZ-VERA GÓMEZ-TRELLES, Javier; SANCINETTI, Marcelo A.; CORDOBA, Fernando, en: JAKOBS, Günther; STRUENSEE, Eberhard, Problemas capitales del derecho penal moderno, Buenos Aires: Editorial Hammurabi, 1998.

36. _ Derecho penal parte general. Fundamentos y teoría de la imputación. Trad.: CUELLO CONTRERAS, Joaquín; SERRANO GONZALEZ DE MOURILLO, José Luís, Madrid: Marcial Pons Ediciones Jurídicas, 1997.

37. _ Fundamentos del derecho penal, Trad: CANCIO MELIÁ, Manuel; PEÑARANDA RAMOS, Enrique, Buenos Aires: Editorial Ad-Hoc, 1996.

38. _ L L L imputación objetiva en el derecho penal, Buenos Aires: Editorial AdHoc, 1996.

39. L La pena estatal: significado y finalidad, Trad: CANCIO MELIÁ, Manuel; FEIJOO SÁNCHEZ, Bernardo; Navarra: Civitas, 2006.

40. _ _ Sobre la normativización de la dogmática jurídico-penal, Trad.: CANCIO MELIÁ, Manuel; FEIJÓO SÁNCHEZ, Bernardo, Madrid: Editorial Civitas, 2003.

41. _ _ Sobre la teoría de la pena, Bogotá: Ed. Universidad Externado de Colombia, 1998.

42. __ Sociedad, norma y persona en una teoría de un derecho penal funcional, Trad.: CANCIO MELIÁ, Manuel; FEIJÓO SÁNCHEZ, Bernardo, Madrid: Editorial Civitas, 2000.

43. JESCHECK, Hans-Heinrich; WEIGEND, Thomas, Tratado de Derecho Penal. Parte General, Trad: OLMEDO, Manuel, Granada: Editorial Comares, $5^{\circ}$ ed., 2002.

44. JIMÉNEZ DE ASÚA, Luis, El criminalista. $2^{\circ}$ Serie. Tomo V, Buenos Aires: Víctor P. de Zavalía, 1961.

45. KINDHÄUSER, Urs, “¿Indiferencia cómo dolo?”; en: KINDHÄUSER, Urs; GARCÍA, Percy; PASTOR, Nuria, Cuestiones actuales de derecho penal general y patrimonial, Lima: Universidad de Piura, 2005.

46. _La fidelidad al derecho como categoría de la culpabilidad", Trad.: MAÑALICH, Juan Pablo, en: KINDHÄUSER, Urs; MAÑALICH, Juan Pablo, Pena y culpabilidad en el estado democrático de derecho, Perú: ARA Editores, 2009.

47. _La lógica de la construcción del delito", Trad.: MAÑALICH, Juan Pablo, Revista de Análisis Especializado de jurisprudencia $\mathrm{n}^{\circ} 14$ (2009).

48. LÓPEZ BARAJA, Jacobo, Tratado de Derecho Penal. Parte General, Navarra: Aranzadí, 2010.

49. LUZÓN PEÑA, Diego Manuel, Estudios Penales, Barcelona: PPU S.A., 1991.

50. MAGGIORE, Giuseppe, Derecho penal - El delito. La pena. Medidas de seguridad y sanciones civiles. Volumen II, Trad.: ORTEGA, José, Bogotá: Temis, $5^{\text {a }}$ Ed., 1989.

51. MANZINI, Vicenzo, Tratado de Derecho Penal. Tomo 1. Primera Parte. Teorías Generales, Trad.: SENTÍS, Santiago, 9ª Ed., Buenos Aires, Ediar, 1949. 
SZCZARANSKI, Federico. “Aproximación a la reiteración delictiva y a la teoría concursal desde la teoría de la pena”

52. , Tratado de Derecho Penal. Tomo 3. Primera Parte. Teorías Generales, Trad.: SENTÍS, Santiago, $9^{a}$ Ed., Buenos Aires, Ediar, 1949.

53. _ Tratado de Derecho Penal. Tomo 4. Primera Parte. Teorías Generales, Trad.: SENTÍS, Santiago, 9ª Ed., Buenos Aires: Ediar, 1949.

54. MAÑALICH, Juan Pablo, "El concurso de delitos: base para su reconstrucción en el derecho penal de Puerto Rico", Revista Jurídica UPR, Vol. 74 (2005).

55. _ _El principio ne bis in idem en el derecho penal chileno", Revista Estudios de la Justicia $\mathrm{n}^{\circ} 15$ (2011).

56. _ _La pena como retribución”, Estudios Públicos n 108 (2007).

57. "Norma e imputación como categoría del hecho punible". REJ $\mathrm{n}^{\circ} 12$ (2010).

58. _ _Pena y ciudadanía", Revista de estudios de la justicia n $\mathrm{n}^{\circ} 6$ (2005).

59. —_ "Retribución como coacción punitiva", Derecho y humanidades n ${ }^{\circ}$ 16 (2010).

60. MATUS, Jean Pierre, "La teoría del concurso (aparente) de leyes en la dogmática alemana, desde sus orígenes hasta el presente (Primera parte)", Ius et Praxis, Vol. 6, $\mathrm{n}^{\circ} 2$ (2000).

61. _L "La teoría del concurso (aparente) de leyes en la dogmática alemana, desde sus orígenes hasta el presente (Segunda parte)", Ius et praxis, Vol. 7, n² (2001).

62. ——_Los criterios de distinción entre el concurso de leyes y las restantes figuras concursales en el código penal español de 1995 (1)”, ADPCP, Vol. LVIII (2005).

63. MAURACH, Reinhart; ZIPF, Heiz, Derecho Penal. Parte General I. Teoría General del derecho penal y estructura del hecho punible, Trad.: BOFILL, Jorge; AIMONE, Enrique, Buenos Aires: Astrea, $7^{\text {a }}$ Ed., 1994.

64. _ Derecho Penal. Parte General II. Formas de aparición del delito y consecuencias del hecho punible, Trad.: BOFILL, Jorge, Buenos Aires: Astrea, $7^{\mathrm{a}}$ Ed., 1995.

65. MAYER, Max Ernst, Derecho Penal. Parte General, Trad.: POLITOFF, Sergio, Montevideo-Buenos Aires, B de f, 2007.

66. MERKEL, Adolf, Derecho penal, Trad.: DORADO, Pedro, Madrid: La España Moderna, 1910.

67. MEZGER, Edmund, Derecho penal. Libro de estudio. Parte general, Buenos Aires: Editorial Bibliográfica Argentina, 1958.

68. — _ Tratado de Derecho Penal. Tomo II, Trad.: RODRIGUEZ, José, Madrid, Editorial revista de derecho privado, $2^{\mathrm{a}}$ Ed., 1957.

69. MIR, Santiago, "Función fundamentadora y función limitadora de la prevención general positiva"; en: BUSTOS, Juan (Dir.), Prevención y teoría de la pena, ConoSur Ltda., 1995.

70. — L Santiago, "Concurso de delitos y concurso de leyes"; en: CONSEJO GENERAL DEL PODER JUDICIAL (ESPAÑA), Temas básicos del derecho: una visión actual, Catalunya, Centre d'Estudis Jurídics i Formació Especialitzada de la Generalitat de Catalunya, 1992.

71. _ _ _ Derecho Penal. Parte General, Barcelona: Reppetor, 9ª Ed., 2011. 
Polít. crim. Vol. 8, № 16 (Diciembre 2013), Art. 5, pp. 500 - 543.

[http://www.politicacriminal.cl/Vol_08/n_16/Vol8N16A5.pdf]

72. __ Santiago, Introducción a las bases del derecho penal. Concepto y método, Montevideo-Buenos Aires: B de F, $2^{\mathrm{a}}$ ed., 2003.

73. MUÑAGORRI, Ignacio, Sanción penal y política criminal. Confrontación con la nueva defensa social, Madrid: Reus, 1977.

74. MUÑOZ CONDE, Francisco, "La resocialización del delincuente análisis y crítica de un mito"; en: Homenaje al profesor J. Antón Oneca, Salamanca: Ediciones Universidad de Salamanca, 1982.

75. PEÑARANDA, Enrique, Concurso de leyes, error y participación en el delito. Un estudio crítico sobre el principio de la unidad de título de imputación, Madrid: Civitas, 1991.

76. RAZ, Joseph, Razón práctica y normas. Trad.: RUIZ, Juan, Madrid: Centro de Estudios Constitucionales, $2^{\text {a }}$ Ed., 1991.

77. ROSS, Alf, On guilt, responsibility and punishment, Berkley and Los Angeles, California: University of California Press, 1975.

78. ROXIN, Claus, "Determinación de la pena a la luz de la teoría de los fines de la pena", Trad.: MUÑOZ CONDE, Francisco; en: ROXIN, Claus, Culpabilidad y prevención en Derecho Penal, Madrid: Reus S.A., 1981.

79. _ Derecho penal. Parte general. Tomo I, Trad.: LUZÓN PEÑA, Diego Manuel; DÍAZ Y GARCÍA CONLLEDO, Miguel; DE VICENTE REMESAL, Javier, Madrid: Civitas, $2^{\mathrm{a}}$ ed., 1997.

80. _ Política criminal y sistema de derecho penal, Trad.: MUÑOZ-CONDE, Francisco, Buenos Aires: Hammurabi, $2^{\mathrm{a}}$ ed., 2002.

81. SANZ MORÁN, Ángel José, "Concurso de delitos en la reforma penal", en CALDERÓN CEREZO, Ángel, Cuadernos de derecho judicial, unidad y pluralidad de delitos, Madrid: Consejo General del Poder Judicial, 1995.

82. SCHÜNEMANN, Bernd, "La función en el principio de culpabilidad en el derecho penal preventivo", Trad.: SILVA SÁNCHEZ, Jesús; en SCHÜNEMANN, Bernd, El sistema moderno de derecho penal. Cuestiones fundamentales, Madrid: Tecnos, 1991.

83. SILVA SÁNCHEZ, Jesús, "Del derecho abstracto al derecho real", InDret, 4 (2006).

84. — El nuevo código penal: cinco cuestiones fundamentales, Barcelona: Bosch, 1997.

85. _L "La teoría de la determinación de la pena como sistema (dogmático): un primer esbozo"; Indret, Abril 2007.

86. STRATENWERTH, Günther, Derecho Penal Parte General I. El hecho punible, Trad.: CANCIO MELIÁ, Manuel; SANCINETTI, Marcelo, Navarra: Aranzadi, 2005.

87. VON BELING, Ernst, Esquema de derecho penal. La doctrina del delito-tipo, Trad.: SOLER, Sebastián, Buenos Aires: El Foro, 2002.

88. VON HIRSCH, Andrew, "Desert and white collar criminality: A response to Dr. Braithwaite", The Journal of criminal Law \& Criminology, Vol. 73, $\mathrm{n}^{\circ} 3$ (1982).

89. , "El concepto de bien jurídico y el <principio del daño>", Trad.: ALCACER, Rafael, en: HEFENDEHL, Roland, La teoría del bien jurídico: 
SZCZARANSKI, Federico. “Aproximación a la reiteración delictiva y a la teoría concursal desde la teoría de la pena”

¿fundamento de legitimación del derecho penal o juego de abalorios dogmáticos?, Madrid: Marcial Pons, 2007.

90. "Proportionate sentences: a Desert perspective"; en: VON HIRSCH, Andrew; ASHWORTH, Andrew; ROBERTS, Julian. Principled sentencing. Reading on theory and policy, Oregon: HART Publishing, 2009.

91. _ "Seriousness, severity and the living standard"; en: VON HIRSCH, Andrew; ASHWORTH, Andrew; ROBERTS, Julian, Principled sentencing. Reading on theory and policy, Oregon: HART Publishing, 2009.

92. , Censurar y castigar, Trad.: LARRAURI, Elena, Madrid: Editorial Trotta S.A., 1998.

93. VON HIRSCH, Andrew; JAREBORG, Nils, "Gauging criminal harm: A livingstandard analysis", Oxford Journal of Legal Studies, Vol. 11 (1991).

94. VON LISZT, Franz, La idea de fin en el derecho penal, México: Instituto de Investigaciones Jurídicas, 1994.

95. VON WRIGHT, Georg Henrik, Norma y acción. Una investigación lógica, Trad.: GARCÍA FERRERO, Pedro, Madrid: Tecnos, 1970.

96. WELZEL, Hans, Derecho penal parte general, Trad: FONTÁN BALESTRA, Carlos; Buenos Aires: Roque De Palma Editor, 1956.

97. ZIFFER, Patricia, Lineamientos de la determinación de la pena, Buenos Aires: AdHoc, 1996.

98. ZIPF, Heinz, "Principios fundamentales de la determinación de la pena", Cuadernos de política criminal $\mathrm{n}^{\circ} 17$ (1982).

99. ZYSMAN, Diego, Castigo y determinación de la pena en los Estados Unidos. Un estudio sobre las United States Sentencing Guidelines. Madrid: Marcial Pons, 2013.

100. Sociología del castigo. Genealogía de la determinación de la pena. Buenos Aires: Didot, 2012. 